Cornell Law Library

Scholarship@Cornell Law: A Digital Repository

Cornell Law Faculty Publications

Faculty Scholarship

$4-1991$

\title{
Wealth, Equity, and the Unitary Medical Malpractice Standard
}

John A. Siliciano

Cornell_LawSchool, jas83@cornell.edu

Follow this and additional works at: http://scholarship.law.cornell.edu/facpub

Part of the Health Law Commons, Medical Jurisprudence Commons, and the Torts Commons

\section{Recommended Citation}

Siliciano, John A., "Wealth, Equity, and the Unitary Medical Malpractice Standard" (1991). Cornell Law Faculty Publications. Paper 1288.

http://scholarship.law.cornell.edu/facpub/1288

This Article is brought to you for free and open access by the Faculty Scholarship at Scholarship@Cornell Law: A Digital Repository. It has been accepted for inclusion in Cornell Law Faculty Publications by an authorized administrator of Scholarship@Cornell Law: A Digital Repository. For more information, please contact jmp8@cornell.edu. 


\title{
ARTICLES
}

\section{WEALTH, EQUITY, AND THE UNITARY MEDICAL MALPRACTICE STANDARD}

\author{
John A. Siliciano*
}

M

AKING a product that is safe or rendering a service in a care-

ful manner is seldom a costless proposition; indeed, increased levels of safety or care are often associated with increased expense. Thus, although a Volvo is safer than a Volkswagen, ${ }^{1}$ it is also more costly. While we well might prefer a different world-one where Volvo safety was available at Volkswagen prices-the technologydependent character of many safety advances often creates tradeoffs between safety and cost. ${ }^{2}$

In the products context, tort law generally acknowledges such tradeoffs by assessing claims of defective design in light of the price the consumer was willing to pay for the product. An individual who purchases an economy car because of its price or low fuel consumption is unlikely, in a subsequent products liability action, to prevail on a theory that the car was not crashworthy because it was too small or too light. ${ }^{3}$ To hold otherwise would unduly impair consumer sover-

* Associate Professor of Law, Cornell Law School. B.A. 1975, Cornell University; J.D. 1979, Columbia Law School; M.P.A. 1979, Princeton University. I wish to thank Randall Bovbjerg, Roger Cramton, George Hay, Alice Hearst, James Henderson, Robert Hillman, Sheri Lynn Johnson, Haavi Morreim, Russell Osgood, Stewart Schwab, and Gary Simson for assisting me with this article.

1 See J. Gillis, The Car Book 18-23 (1989).

2 For example, with respect to automobiles, many significant safety advances, such as airbag passive restraint systems, antilock brakes, and seatbelts with crash-sensitive pretensioning devices, appear only as standard items on more expensive automobiles; on less expensive cars, such devices are optional, if they are available at all. Id. at 29-32, 144-45.

3 See Seattle - First Nat'1 Bank v. Tabert, 86 Wash. 2d 145, 154, 542 P.2d 774, 779 (1975) ("purchaser of a Volkswagen cannot reasonably expect the same degree of safety as would the buyer of the much more expensive Cadillac"); cf. Dawson v. Chrysler Corp., 630 F.2d 950, 957 (3d Cir. 1980) ("risk/utility" analysis is the basis for determining whether a product is defective), cert. denied sub nom. Chrysler Corp. v. Dawson, 450 U.S. 959 (1981); Wilson v. Piper Aircraft Corp., 282 Or. 61, 67-68, 577 P.2d 1322, 1326, reh'g denied, 282 Or. 411,579 
eignty, for if all cars must be as safe as Volvos, what will those who cannot pay the sticker price be able to drive?

When the focus shifts from products to services, care replaces safety as the relevant concern; the basic constraint, however, remains the same. As those who have handled major litigation matters know, there is seemingly no end to the amount of work involved in careful preparation of a case. Instead, the limit is often mandated by a simple need to contain costs. Thus, in the end, the provision of perfect care may be restrained by the practical concern of cost.

This tradeoff is perhaps most evident in the world of modern medicine. The diagnostic and remedial technologies available to medical practitioners today are vastly more powerful than those available a generation ago, yet they are also far more expensive. For the welloff-in this context, the fully insured-the higher cost of improved care does not pose a serious problem. ${ }^{4}$ For those lacking full insurance, however, and particularly for the medically indigent-those 35 million Americans, or $15 \%$ of the population, without any health insurance ${ }^{5}$ - the promise of modern medicine is often beyond reach. ${ }^{6}$

P.2d 1287 (1978) (en banc) (court balances safety concerns against expense and utility to determine liability). In contrast, such a plaintiff might well prevail on a claim that the car was unreasonably unsafe for a car of its size and cost.

4 Indeed, many have argued that comprehensive medical insurance, if administered on a fee-for-service basis, may encourage excessive consumption of expensive medical care. See, e.g., Waters \& Tierney, Hard Lessons Learned, 311 New Eng. J. Med. 1251, 1251 (1984).

5 Fuchs, The Counterrevolution in Health Care Financing, 316 New Eng. J. Med. 1154, 1155 (1987). The medically indigent segment of the population is comprised of poor persons who do not qualify for Medicaid coverage, many unemployed or self-employed individuals, employees of many small businesses that do not provide health care coverage, elderly persons requiring extended care and related services not covered by Medicare, and persons who are uninsurable because of specific preexisting medical conditions. Nutter, Medical Indigency and the Public Health Care Crisis: The Need for a Definitive Solution, 316 New Eng. J. Med. 1156, 1156 (1987).

In addition to the uninsured, an approximately equal number of the population is underinsured, that is, lacking adequate health insurance to cover the expected costs of ordinary medical care. Bovbjerg \& Kopit, Coverage and Care for the Medically Indigent: Public and Private Options, 19 Ind. L. Rev. 857, 857 (1986).

6 Federal and state programs for health care assistance for the poor-most notably Medicare and Medicaid-have helped alleviate the problem of medical indigence for many. But with the waning of society's commitment to such programs during the last decade, see Vladeck, Equity, Access, and the Costs of Health Services, 3 Securing Access to Health Care 3 (1981); Waters \& Tierney, supra note 4, at 1251-52, the numbers of the medically indigent have risen, and the pressure on alternative means to insure equitable treatment for the poorincluding tort law-has correspondingly increased. See infra note 59 and accompanying text. See generally Davis \& Rowland, Uninsured and Underserved: Inequities in Health Care in the 
This widening gap between the costs of medical care and the ability of some potential consumers to pay creates a dilemma for tort law in determining the standard of reasonable medical care. Following its approach with respect to other goods and services, one might naturally expect tort law, in assessing the care rendered to an indigent patient, to take account of the resources available to finance that care. This, however, has not been the case. To date, medical malpractice law has refused to recognize formally the economic status of the patient as a factor legitimately influencing the kind or degree of care the patient receives. ${ }^{7}$ Instead, malpractice claims are assessed against a unitary, wealth-blind standard of care. ${ }^{8}$ As one court explained, "[w] hether the patient be a pauper or a millionaire, whether he be treated gratuitously or for reward, the physician owes him precisely

United States, 3 Securing Access to Health Care 55 (1982) (statistical survey of levels of insurance and use of medical care among various segments of the United States population, with focus on disparities along racial and economic lines).

7 See, e.g., President and Directors of Georgetown Coll. v. Hughes, 130 F.2d 810, 827 (D.C. Cir. 1942); Tunkl v. Regents of the Univ. of Cal., 60 Cal.2d 92, 103-04, 383 P.2d 441, 448, 32 Cal. Rptr. 33, 40 (1963); Rule v. Cheeseman, 181 Kan. 957, 963, 317 P.2d 472, 477 (1957); Becker v. Janinski, 15 N.Y.S. 675, 677 (1891). Commentators have likewise noted the assumptions of equal care in tort standards. See, e.g., Atiyah, Medical Malpractice and the Contract/Tort Boundary, 49 Law \& Contemp. Probs. 287, 297 (1986) (health care has carried with it the same tort standard of reasonable care); Morreim, Cost Containment and the Standard of Medical Care, 75 Calif. L. Rev. 1719, 1725 (1987) (discussing the general tort doctrine that patient's ability to pay is irrelevant).

8 This is not meant to suggest that wealth disparities do not, as a practical matter, have a significant impact on the care that a patient receives. Indeed, numerous factors have historically resulted in the poor receiving less care, and lower quality care, than the well-off. See Starr, Medical Care and the Pursuit of Equality in America, 2 Securing Access to Health Care 3 (1982); see also Hadley, Steinberg \& Feder, Comparison of Uninsured and Privately Insured Hospital Patients, 265 J. Am. Med. Assoc. 374 (1991) [hereinafter Hadley] (demonstrating empirically that hospitals generally devote significantly fewer resources to uninsured patients). For example, many jurisdictions do allow the malpractice standard to vary according to locality or specialty, see McCoid, The Care Required of Medical Practitioners, 12 Vand. L. Rev. 549, 558-75 (1959), and, as discussed below, such rules may implicitly recognize wealth as a factor affecting the standard of care. See infra text accompanying notes 121-42. Even apart from the legal standard, geography and demographics are likely to affect the actual standard of care provided. Affluent areas, for instance, are typically served by better equipped hospitals with better trained staffs. Moreover, medical care in greater amounts and of higher quality has typically been available in the marketplace for those willing and able to pay a premium. See Fuchs, The "Rationing" of Medical Care, 311 New Eng. J. Med. 1572 (1984). Finally, despite the command of the unitary standard, it appears that the insurance status of a patient subtly, and perhaps unconsciously, influences the multiple discretionary judgments about care that a provider typically makes, resulting in a de facto dual care standard. See Hadley, supra. 
the same measure of duty, and the same degree of skill and care." The sentiment underlying this unitary perspective is both obvious and laudable. Although perhaps not a fundamental right, ${ }^{10}$ health is certainly a fundamental value, ${ }^{11}$ one which the tort system, through the structure of its liability rules, might seek to distribute as widely as possible through society.

Despite the unitary standard's moral appeal, however, this Article contends that tort law's effort to promote an equitable distribution of health care benefits is fundamentally ineffectual, and, as a result, is misguided. As support, the Article might simply point to the reality, well-recognized outside of tort law, that wealth disparities do as a practical matter significantly affect the care received by a patient. ${ }^{12}$ But the purpose here is not simply to observe that the unitary malpractice standard is currently failing to achieve its goal, but also to question whether tort law's impulse towards equity in the provision of health care can ever be realized when another central feature of medical malpractice law is its ready acceptance of the essentially contractual nature of the American system of health care delivery. From a legal perspective, ${ }^{13}$ physicians and hospitals are free, with limited exc-

9 Becker v. Janinski, 15 N.Y.S. 675, 677 (1891).

10 Cf. Harris v. McRae, 448 U.S. 297, 318 (1980) (no constitutional right to public funding of a medically necessary abortion); Maher v. Doe, 432 U.S. 464, 469 (1977) (same conclusion with respect to medical care for pregnancy). Public opinion, however, tends to favor strongly the idea of a "right" to health care, although this sentiment is generally not matched by a willingness to pay the full costs of securing such a right. See Blendon, What Should Be Done About the Uninsured Poor?, 260 J. A.M.A. 3176 (1988). For a thorough discussion of the right to health care debate, see Bovbjerg \& Kopit, supra note 5, at 871-74.

11 See, e.g., Fried, Rights and Health Care-Beyond Equity and Efficiency, 293 New Eng. J. Med. 241, 243 (1975) ("The physician who withholds care that it is in his power to give because he judges it is wasteful to provide it to a particular person breaks faith with his patient."); Hiatt, Protecting the Medical Commons: Who is Responsible?, 293 New Eng. J. Med. 235, 239 (1975) ("A physician or other provider must do all that is permitted on behalf of his patient.... The patient and the physician want no less, and society should settle for no less."); Levinsky, The Doctor's Master, 311 New Eng. J. Med. 1573, 1575 (1984) ("unlimited availability of useful medical care has been perceived as a right in American society").

12 See supra note 8.

13 Most states, either by statute or judicial decision, require hospitals to provide emergency treatment to all patients regardless of resources. See, e.g., Thompson v. Sun City Community Hosp., 141 Ariz. 597, 602, 688 P.2d 605, 610 (1984); Mercy Medical Center v. Winnebago County, 58 Wis. 2d 260, 267-68, 206 N.W.2d 198, 201 (1973). See generally N. Chayet, Legal Implications of Emergency Care (1969) (discussion of the legal aspects of the treatment of medical trauma, including a survey of Good Samaritan statutes); Dowell, Indigent Access to Hospital Emergency Room Services, 18 Clearinghouse Rev. 483 (1984) (study of state emergency room statutes). Even under such conditions, however, the hospital is generally free 
ceptions, to decline treatment to those who cannot afford the cost of care. ${ }^{14}$ Thus, any theoretical defense of the current unitary standard must explain how tort law can achieve its goal of providing the same quality of care to all Americans when providers have the liability-free option of providing no care at all to whomever they choose. ${ }^{15}$

This Article concludes that it cannot. While the particular structure of the market for medical services described in Part One may have obscured this tension in the past, recent and rapid changes in the technology of health care, the systems of reimbursement, and the reaction of the medical profession to liability concerns have sharpened the conflict between tort law's aim of promoting equity in the provision of care and economic factors limiting the medical profession's interest in providing service to nonpaying patients. ${ }^{16}$ The Article then

to discharge the patient after the patient's condition has "stabilized" and arrangements for transfer of the patient have been made. See St. Joseph's Hosp. v. Maricopa County, 142 Ariz. 94, 97, 688 P.2d 986, 989 (1984); see also Annas, Adam Smith in the Emergency Room, 15 Hastings Center Rep., Aug. 1985, at 16, 17 (noting that transfers are permissible when "immediate" treatment is not necessary, and the patient can be moved without foreseeable risk to the patient's health); Ansell \& Schiff, Patient Dumping: Status, Implications and Policy Recommendations, 257 J. A.M.A. 1500 (1987) (noting a dramatic increase in transfers of those needing emergency care); McIntire, The Action of Abandonment in Medical Malpractice Litigation, 36 Tul. L. Rev. 834 (1962) (physicians' abandonment of patients discussed as a type of medical malpractice). Moreover, the emergency treatment requirement applies only to hospitals; physicians, as a rule, remain free to refuse to treat individuals even in emergency situations. See, e.g., Hurley v. Eddingfield, 156 Ind. 416, 59 N.E. 1058 (1901) (no state requirement for a licensed physician to enter into contracts for medical care). For a comprehensive discussion of the various means by which the medically indigent may gain access to health care, see Bovbjerg \& Kopit, supra note 5, at 874-91.

14 See, e.g., Wilmington Gen. Hosp. v. Manlove, 54 Del. 15, 21, 174 A.2d 135, 138 (1961); Hurley v. Eddingfield, 156 Ind. 416, 59 N.E. 1058 (1901). See generally Curran, Breaking Off the Physician-Patient Relationship: Another Legal Standard, 307 New Eng. J. Med. 1058, 1058 (1982) ("The practice of medicine in the United States is still a matter of free determination."). Once a physician has undertaken to treat a patient, however, he may not terminate the relationship until the patient no longer requires care or until the patient has been given an adequate opportunity to find alternative care. Id.; see also McIntire, supra note 13, at 835-36 (noting that the physician-patient relationship continues until terminated by the parties or until medical care is no longer needed).

15 See Howard, Medical Malpractice Liability and Cost Containment: Law and Economics in Conflict, 43 Food Drug Cosm. L.J. 309, 324 n.124 (1988) ("Medical malpractice law may fail to protect the poor ... [because] . . . it does not reach the major device used to withhold treatment from the poor, i.e., preventing the physician-patient relationship from coming into existence in the first place....").

16 One commentator has argued that "[ $t]$ he standards of practice that may result from the response of physicians to ... economic constraints and to incentives intended to lower the aggregate cost of health care have yet to be reconciled with the body of law that pushes 
considers whether, in light of this conflict, tort law's continued insistence on a unitary malpractice standard furthers either the interests of the class it is specifically intended to serve-the medically indigentor the more general interests of the tort system and society.

Concluding that the poor are likely to be disserved by the unitary standard, and that alternative justifications are elusive, the Article suggests that tort law should recognize that resource-based distinctions in the quality of available health care are, to a certain extent, inevitable. This does not mean, however, that the poor should be denied legal protection from incompetent medical care. ${ }^{17}$ Tort law can, and should, remain concerned with whether the challenged medical intervention was reasonable, and, to this extent, the unitary standard retains vitality.

Even so, tort law must also recognize the fact that the poor are poor, a fact which, given this country's persistent refusal to finance full health care for all its citizens, is unlikely to change. Accordingly, the reasonableness of the amount and kinds of treatment provided the indigent can be realistically assessed only in light of this stark and entrenched reality. To this end, the Article suggests that the malpractice standard be modified to expressly encompass patient resources as a factor bearing on the legal adequacy of the care provided. Such a step is undoubtedly painful in its symbolic connotations. ${ }^{18}$ It exposes an embarrassing discrepancy between the ideals we preach and the actions we are actually prepared to take. And adoption of a resource-

physicians to ignore costs ...." Stone, Law's Influence on Medicine and Medical Ethics, 312 New Eng. J. Med. 309, 310 (1985). For a detailed treatment of the recent changes in the medical profession and their impact on the standard of medical care, see Howard, supra note 15; Macaulay, Health Care Cost Containment and Medical Malpractice: On a Collision Course, 21 Suffolk U.L. Rev. 91 (1986); Morreim, supra note 7; Comment, A Cost Containment Malpractice Defense: Implications for the Standard of Care and for Indigent Patients, 26 Hous. L. Rev. 1007 (1989).

17 See infra text accompanying note 128.

18 Cf. Welch, Health Care Tickets for the Uninsured: First Class, Coach, or Standby?, 321 New Eng. J. Med. 1261 (1989), in which the author writes:

To many people, the realization that "adequate" care may be something less than "optimal" will be upsetting. ... In a country where first-class medical care is perceived to be an inalienable right, the designation of a coach class may seem unjust. Yet the rhetoric of those who fear the creation of a two-tiered system ignores the fact that multiple tiers currently exist. The proponents of first-class insurance simply promise more than can be delivered, and for a number of reasons uncompensated or standby care can no longer be tolerated.

Id. at 1263. 
sensitive malpractice standard runs the risk of making tort law appear to be "against the poor." But surface appearances easily deceive, and, as this Article suggests, the proposed modification of the malpractice standard may far better serve the poor's interest in receiving adequate health care than tort law's current effort to mandate equity by fiat.

\section{Malpractice AND The Market for Medical SeRvices}

\section{A. A Basic Model of Patient Care}

Conceivably, the degree of care a patient receives from a physician or other health care provider ${ }^{19}$ could be determined solely by contract. $^{20}$ The patient's decision to seek care and the physician's agreement to render care, coupled with the physician's recommendation that a certain course of treatment be utilized and the patient's informed consent to that treatment, certainly suggest the type of voluntary bargain characteristic of traditional contract law. ${ }^{21}$ Viewed from this perspective, the decision regarding the level of care to be provided in the medical context would be similar to that with respect to any other service: the parties' agreement over the quality of services would control, with better or more extensive care typically coming at a higher cost. ${ }^{22}$ In this pure market model, tort law would have little or no role to play, except perhaps by providing a remedy for fraud in the transaction or for negligence so gross that no competent party would consent to its commission. ${ }^{23}$

19 Increasingly, the care provider will be a hospital or similar enterprise, for which the treating physician merely serves as an employee. See Relman, The New Medical-Industrial Complex, 303 New Eng. J. Med. 963 (1980).

20 For a comprehensive contractual approach to the problem of medical malpractice, see $\mathbf{R}$. Epstein, "Medical Malpractice: Its Cause and Cure," in The Economics of Medical Malpractice 245 (S. Rottenberg ed. 1978); Epstein, Medical Malpractice: The Case for Contract, 76 Am. B. Found. Res. J. 87 (1976); Havighurst, Reforming Malpractice Law Through Consumer Choice, 3 Health Aff., Winter 1984, at 63. For a critical appraisal of the contractual approach, see P. Danzon, Medical Malpractice: Theory, Evidence, and Public Policy 209-213 (1987); Rosenblatt, Health Care, Markets and Democratic Values, 34 Vand. L. Rev. 1067 (1981).

21 See Atiyah, supra note 7, at 291-92 ("the doctor-patient relationship is, in most cases, rooted in a straightforward purchase of services, and nineteenth-century lawyers would surely have seen the relationship as primarily contractual").

22 In this respect, the decision to purchase medical services might be viewed similarly to the decision to employ a house painter or a roofer, two situations in which the quality of the service is notoriously related to its price.

${ }^{23}$ See generally R. Posner, Economic Analysis of Law 96-101 (3d ed. 1986) (discussion of the role of fraud and the duty to disclose material information in contracts of sale). 
Tort law, however, has seldom adopted a purely contractual genesis for the duty of care. ${ }^{24}$ In the products liability area, for example, courts have generally declined to honor warranty disclaimers affecting the standard of care on the ground that consumers are too powerless and ill-informed to bargain effectively with producers. ${ }^{25}$ Similar concerns surface in the medical area. The quasi-fiduciary nature of the physician's role, the vulnerability and possible incompetence of the patient, the exigency that often surrounds illness, and the tremendous complexity of modern medicine all serve to impair the prospects for effective bargaining over the scope and nature of treatment rendered by the physician. ${ }^{26}$

Consequently, the standard of care in the medical context is generally not derived from the bargaining between the parties ${ }^{27}$ but is instead set by the prevailing custom of the medical community. ${ }^{28}$ In

24 See Siliciano, Corporate Behavior and the Social Efficiency of Tort Law, 85 Mich. L. Rev. 1820, 1823-25 (1987).

25 See, e.g., Henningsen v. Bloomfield Motors, Inc., 32 N.J. 358, 391, 161 A.2d 69, 87 (1960). See generally Priest, The Invention of Enterprise Liability: A Critical History of the Intellectual Foundations of Modern Tort Law, $14 \mathrm{~J}$. Legal Stud. 461 (1985) (addressing the intellectual origins of modern tort doctrine's abandonment of the contract regime).

26 See P. Danzon, supra note 20, at 139-43; Arrow, Uncertainty and the Welfare Economics of Medical Care, 56 Am. Econ. Rev. 941, 951 (1963); Atiyah, supra note 7, at 295-98; Ginsburg, Kahn, Thornkill \& Gambardella, Contractual Revisions to Medical Malpractice Liability, 49 Law \& Contemp. Probs. 253, 253-55 (1986) [hereinafter Ginsburg]; Havighurst, Altering the Applicable Standard of Care, 49 Law \& Contemp. Probs. 265, 265 (1986); Henderson, Contractual Problems in the Enforcement of Agreements to Arbitrate Medical Malpractice, 58 Va. L. Rev. 947, 960-66 (1972); Relman, supra note 19, at 966.

27 Indeed, courts have traditionally been hostile towards efforts to modify the standard of care through private ordering. See, e.g., Tunkl v. Regents of the Univ. of Cal., $60 \mathrm{Cal} .2 \mathrm{~d} 92$, 101-03, 383 P.2d 441, 446-47, 32 Cal. Rptr. 33, 42-44 (1963); Ginsburg, supra note 26, at 25355. This is not meant to suggest that the agreement between the parties is irrelevant to the standard by which the treatment will be judged. Absent consent by the patient, most forms of medical intervention would, at least technically, constitute a battery. Thus, if the physician's treatment extends to ailments or areas beyond the scope of the patient's consent, liability may be triggered even if the care is nonnegligent. See, e.g., Bang v. Charles T. Miller Hosp., 251 Minn. 427, 434, 88 N.W.2d 186, 190 (1958) (holding that medical treatment not consented to by the patient constitutes a basis for malpractice). See generally McCoid, A Reappraisal of Liability for Unauthorized Medical Treatment, 41 Minn. L. Rev. 381 (1957) (analyzing unauthorized medical treatment as a form of malpractice). In such cases, the cause of action essentially sounds in battery rather than in negligence.

28 See P. Danzon, supra note 20, at 140 (noting that courts have generally deferred to custom on grounds that the layperson is unable to evaluate technical medical judgments); King, In Search of a Standard of Care for the Medical Profession: The "Accepted Practice" Formula, 28 Vand. L. Rev. 1213, 1234-44 (1975) (discussing the "accepted practice" standard for determining liability). 
order to prevail, a plaintiff in a malpractice action must show that the care provided fell short of the level accepted as reasonable by the relevant segment of the medical community. ${ }^{29}$ In this regard, tort law supplements the voluntary agreement between physician and patient by implying a unitary standard governing the care exercised by the health care provider. ${ }^{30}$

This intervention of tort law into the physician-patient relationship, however, is insufficient to strip that relationship of its contractual underpinnings. Hence, while tort law creates a fixed standard against which the delivery of care can be assessed, the health care provider remains free, in most contexts, ${ }^{31}$ to insist on adequate compensation for the care thus mandated. If the patient is unable to pay the costs of such care, the provider has at least two options of relevance here. First, it can simply decline to accept the patient for treatment, thus relying on the contractual gateway to health care as a means of avoiding tort law's insistence on a unitary standard of care. Alternatively, it can acquiesce in its basic impulse towards equity-an impulse reinforced by the Hippocratic Oath and other professional ideals-and attempt to handle the financial shortfall of uncompensated care by charging paying patients a premium to cover the treatment provided their poorer brethren. The feasibility of this second, collectivist approach to the problem of uncompensated care, upon which the full success of tort law's unitary standard for malpractice is implicitly predicated, is now examined.

29 King, supra note 28 , at 1234 .

30 See R. Posner, supra note 23, at 153 ("The doctor implicitly promises to treat the patient with the care customary among doctors in the area. If he does not use that much care he is guilty of malpractice, a tort, but he has also and by the identical conduct violated his contract with the patient.").

31 As previously discussed, hospitals are generally required to provide emergency care regardless of patient resources. See supra note 13 and accompanying text. Legislatures occasionally seek to mandate broader coverage for the indigent. For example, Congress requires hospitals receiving federal funds for construction to provide "a reasonable volume of services to persons unable to pay." Hill-Burton Act, 42 U.S.C. § 291c(e) (1971). Efforts to give substance to this statutory requirement, however, have been largely unavailing. See generally Rose, Federal Regulation of Services to the Poor Under the Hill-Burton Act: Realities and Pitfalls, 70 Nw. U.L. Rev. 168 (1975) (arguing that the department responsible for enforcing the obligations created by the Act has completely failed in its efforts to do so); Rosenblatt, Health Care Reform and Administrative Law: A Structural Approach, 88 Yale L.J. 243 (1978) (congressional goal of securing health care access frustrated by administrative practices). 


\section{B. Incentives Favoring a Collective Resource Approach}

Courts and commentators defending the unitary malpractice standard seldom articulate how that standard can possibly function effectively in a world where consumer indigence is common, and the provider's freedom not to treat is an accepted premise. Their answer seemingly would have to rest on the assumption that health care providers, rather than simply limiting their services to paying clients, will follow their equitable impulses and actively seek to charge paying clients a premium in order to cover the costs of providing free or undercompensated care to the poor.

A generation ago, this assumption comported well with reality; hospitals and physicians routinely overcharged some patients to finance the care of other patients. ${ }^{32}$ At first glance, such conduct is hard to square with rational economic behavior. It is necessary to explain, for example, why the medically well-off would tolerate a pricing system for health care services that charged them for the care rendered to others. ${ }^{33}$ It is equally important to fathom why health care providers, if blessed with such an apathetic consumer population, would have any incentive to use the surplus thus extracted for the poor rather than for themselves. These tensions between predicted economic behavior and the conduct implicitly envisioned by the unitary standard of care raise an even more fundamental question of why, until recently, the unitary standard has largely gone unquestioned by both the medical profession and the legal academy. ${ }^{34}$ The answer to this puzzle appears to lie in a collection of factors which, at least in the past, may have made health care providers both able and

32 See Dolenc \& Dougherty, DRGs: The Counterrevolution in Financing Health Care, 15 Hastings Center Rep., June 1985, at 19, 21; Ginzberg, The Destabilization of Health Care, 315 New Eng. J. Med. 757, 759 (1986); Sager, Why Urban Voluntary Hospitals Close, 18 Health Servs. Res. 451, 457 (1983).

33 Of course, systems of government taxation and largess often fulfill this redistributive function, but they are essentially coercive rather than voluntary. Thus, they fail to explain why consumers in an essentially free and private market would accept systematic overpricing rather than seek out health care providers with more competitive prices.

34 See Atiyah, supra note 7, at 297 ("Although in practice, of course, nobody could suppose that the wealthy have not been able to obtain better quality treatment and care, the community has not had to openly face the uncomfortable idea that the law approves variations in the standards of health care according to the means of the sick."). 
willing to collectivize consumer resources in order to provide, albeit in a rough sense, a unitary level of health care to rich and poor alike. ${ }^{35}$

The medical marketplace of a generation ago was considerably less competitive than that of today, and thus provided more opportunity for health care providers to charge above-market rates ${ }^{36}$ to some consumers in order to create the surplus necessary to cover the costs of uncompensated care. Profession-based restrictions on the supply of physicians, along with the lack of significant competition from paraprofessional health care delivery personnel, gave physicians considerable market power and stymied consumer efforts to secure health care through alternative means. The physician-patient relationship, as yet largely untainted by the consumer-oriented doctrine of informed consent, ${ }^{37}$ was paternalistic and fiduciary in nature, and thus encouraged health care consumers to acquiesce in the decisions of their physicians. Not only did these factors give physicians significant control over health care delivery, but they also muted the competitive pressures that might otherwise contain the charges for health care services.

Competition in the health care market was further subdued by existing methods of reimbursement and the widespread use of thirdparty insurance for health care costs. Until recently, most charges for medical care, whether stemming from a physician or a hospital, were paid on an individualized and retrospective fee-for-service basis. ${ }^{38}$ In other words, after accepting the patient for care, the health care provider was largely free to determine, in an ongoing and open-ended manner, what tests and procedures to order. One collateral effect of this partial ex ante indeterminacy of the care to be provided was to obscure a similar vagueness in the precise amount to be charged for

35 As previously noted, regardless of the malpractice standard, the well-off and the poor have never received identical medical care. See supra note 8 and accompanying text. This Article considers only the marginal impact malpractice law has on this problem, while recognizing that tort law's role may well be dwarfed by other influences, such as the amount of public resources committed to the health care of the poor.

36 That is, rates which include a surcharge to finance care for the indigent, with the surcharge being an amount that perfectly informed (and individual wealth-maximizing) consumers in a competitive market presumably would be unwilling to pay.

37 See, e.g., Canterbury v. Spence, 464 F.2d 772 (D.C. Cir. 1972) (noting that lack of informed consent could serve as a basis for liability).

38 See Dolenc \& Dougherty, supra note 32, at 19. 
services actually rendered. In fact, the patient's financial capacity was often implicitly considered in determining the ultimate bill for care.

Nor were well-off patients particularly inclined to challenge high medical charges when such costs were largely covered by insurance. Of course, insurance functions largely to redistribute losses temporally without reducing the overall average cost to the insured. ${ }^{39}$ Yet the fact that the consumer experiences such costs as even and predictable premiums rather than large, sporadic medical bills significantly decreases, as a practical matter, the consumer's interest in questioning specific medical charges. ${ }^{40}$ In cases where the insurance costs are picked up by the government or the consumer's employer, the consumer's direct incentives to monitor costs are obviously further suppressed.

While the above factors permitted health care providers to extract some surplus from consumers, other forces encouraged them to use these funds to provide care to the poor. Foremost among these, of course, was the medical profession's traditional ethical commitment to providing health care to all those in need. ${ }^{41}$ Indeed, the profession viewed its practice of charging a premium to well-off patients not as simply what the market would tolerate, but as something that allowed it to pursue more thoroughly its mission of treating the sick. To this extent, application of a unitary care standard furthered tort law's effort to foster quality health care for the poor simply by encouraging health care providers to do what they were, for the most part, ${ }^{42}$ already well inclined to do.

In addition to the profession's ethical norm of providing treatment for the poor, the more limited medical technologies of the past meant that the cost of treating the medically indigent in a manner similar to

39 In fact, the average cost to the consumer is higher when insurance is employed because of the premium paid to the insurer to perform the risk-bearing and loss-spreading function. See Posner, Trends in Medical Malpractice Insurance, 1970-1985, 49 Law \& Contemp. Probs. 37 (1986); Roddis \& Stewart, The Insurance of Medical Losses, 1975 Duke L. J. 1281, 1281-89.

40 See Thurow, Medicine Versus Economics, 313 New Eng. J. Med. 611, 612 (1985); see also Boyle, Should We Learn to Say No? 252 J. A.M.A. 782 (1984) (discussing physician's duty to protect patient from receiving inadequate care); Fuchs, supra note 5, at 1154 (noting that third-party reimbursement is one cause of the overuse of services).

41 See supra note 11.

42 Of course, even under such circumstances, some medical practitioners undoubtedly declined to treat the poor. The argument advanced here is a marginal rather than an absolute one: the medical marketplace of a generation ago was more receptive to the efforts of health care professionals to finance indigent care than is true today. 
the medically well-off was not necessarily significant. In a world lacking sophisticated diagnostic techniques and complex surgical or pharmacological methods of cure, the cost of caring for the poor was more closely bound simply to the cost of the care provider's time. Thus, for example, a portion of the charge for an office visit by a paying patient might be used to subsidize the cost of providing the same office visit to a nonpaying patient.

In short, the past combination of market structure, professional ethics, and relatively inexpensive medical technology made possible the collectivization of patient resources necessary for the practical operation of the unitary malpractice system. ${ }^{43}$ Indeed, in the context of these factors, the equity-promoting directive of tort law approached redundancy, for it merely reiterated what the medical profession generally demanded of itself. Probably for this reason, the unitary malpractice standard was seldom questioned. As outlined below, however, the conditions that once stilled objection have eroded considerably, and with this change comes both the impulse and the need to reexamine the unitary standard.

\section{Medicine in the New Age}

Medicine since the early 1980 s has been marked by increasing competition among health care providers, heightened calls for the control of escalating medical costs, and a relentless growth in the complexity and costs of medical technology. These forces have combined to debilitate significantly the de facto system of cross-patient subsidization that, in the past, enjoyed some success in equalizing medical care across economic classes.

The once reserved profession of medicine is increasingly marked by unabashed competition among heatlth care providers. ${ }^{44}$ This is

43 This is not to suggest that such factors eliminated wealth-based disparities in the delivery of health care. Some degree of differential treatment and access has always been present in the American health care system. See Dallek, Commentary, 36 Case W. Res. L. Rev. 969 (1986). Rather, the argument here is that a variety of factors in the past muted the contrast to a sufficient degree that the oddity of the unitary standard went largely unnoticed.

44 See generally Ginzberg, The Monetarization of Medical Care, 310 New Eng. J. Med. 1162 (1984) (describing the transformation of the medical profession into a money-driven business and commenting on possible constraints); Havighurst, Competition in Health Services: Overview, Issues and Answers, 34 Vand. L. Rev. 1117 (1981) (suggesting that competition would direct the growth of health care in the 1980 s and discussing various problems this would raise). For a general overview of the structural problems of the modern 
plainly true among physicians, where deliberate increases in medical school enrollments have raised significantly the number of physicians in proportion to the population. ${ }^{45}$ Not only has competition warmed inside the physician corps, but an increasing variety and number of paraprofessionals now seek to service the more routine needs of the patient population. With these changes, and perhaps as a result of them, there has been an increased business orientation on the part of many health care providers. ${ }^{46}$ The profession's traditional ethical mandate to care for the poor has been tempered, and in some cases eroded, by a concern for the bottom line. ${ }^{47}$

As competition has increased on the supply side of the medical marketplace, significant changes have occurred in the legal system's conception of the status of consumers in the health care system. The traditionally deferential attitude of courts toward the decisionmaking autonomy of physicians has to a considerable extent given way to a more consumer-oriented outlook. The rise of malpractice litigation, the maturation of the informed consent doctrine, the push toward national standards of accepted practice, and the occasional forays of courts into the realm of medical custom all evince an increased willingness on the part of the legal system to sanction consumer challenges to the profession's decisionmaking hegemony.

health care delivery system, see Davies \& Felder, Applying Brakes to the Runaway American Health Care System: A Proposed Agenda, 263 J. A.M.A. 73 (1990).

45 From 1970 to 1986, the number of physicians per 100,000 population grew from 148 to 220. Ginzberg, A Hard Look at Cost Containment, 316 New Eng. J. Med. 1151, 1152 (1987).

46 This trend has been accelerated by the rise of for-profit medical care and the corresponding change in status of many physicians from self-employed to that of an employee of a profit-making institution. See Relman, supra note 19. In such cases, physicians often face a direct conflict between the financial interests of their employer and the needs of the patient. Cf. Levinsky, supra note 11 (arguing that this conflict should not exist, as physicians must serve the needs of patients despite societal interests). Under such circumstances, even the provision of adequate care to insured patients may be jeopardized, and hence the treatment of indigent patients may be viewed as an unaffordable luxury. See Levey \& Hesse, Bottom-Line Health Care?, 312 New Eng. J. Med. 644, 645 (1985) ("When financial goals are preeminent, provision of charitable services seems contrary to an institution's best interests."); Nutter, Access to Care and the Evolution of Corporate, For-Profit Medicine, 311 New Eng. J. Med. 917 (1984); see also Angell, Cost Containment and the Physician, 254 J. A.M.A. 1203 (1985) (calling for identification and curtailment of unnecessary medical care, rather than the rationing of beneficial technologies).

47 See Boyle, supra note 40, at 782-83; Relman, Practicing Medicine in the New Business Climate, 316 New Eng. J. Med. 1150 (1987). 
This increased scrutiny regarding the nature of medical care has been matched by a heightened societal concern over the price of medical care. Widescale changes in reimbursement and insurance practices have turned the attention of consumers and their insurers to the cost and nature of treatment. ${ }^{48}$ This transformation is most notable with respect to the ongoing shift, beginning with the Medicare program in 1983, from reimbursement based on a retrospective, patient specific, fee-for-service basis to a prospective, fixed payment system based on the patient's general diagnosis. Under this Diagnostic Related Group (DRG) method, the health care provider is entitled to a specific payment depending on the patient's diagnosed condition. If the care provided is less costly than the set fee, the provider keeps the surplus; shortfalls in the other direction are absorbed by the provider. ${ }^{49}$

Thus, under a DRG reimbursement system, the financial survival of the provider generally depends on its ability to keep the average cost of care for each diagnostic group within the payment allotted for that diagnosis. This incentive directly circumscribes the provider's ability to supply care to the indigent. Because DRG reimbursement payments are set simply by category of diagnosis, there is no possibility of assessing surplus charges against some patients in order to subsidize the care of others who are not similarly covered by some form of health insurance. Moreover, the central focus in establishing such reimbursement schedules is to provide reasonable compensation for the average costs of treating one patient with a given diagnosis; little

48 See generally Capron, Containing Health Care Costs: Ethical and Legal Implications of Changes in the Methods of Paying Physicians, 36 Case W. Res. L. Rev. 708 (1986) (changes in physician payment mechanisms must be both economically and ethically sound); Fuchs, supra note 5 (observing the increased concern about treatment and predicting increased involvement of the federal government in health care).

49 See generally Dolenc \& Dougherty, supra note 32 (noting that DRG system may contain costs, but will restrict the quality and extent of health care); Iglehart, Medicare Begins Prospective Payment of Hospitals, 308 New Eng. J. Med. 1428 (1983) (outlining the DRG prospective payment legislation and noting the financial problems it will create for Medicare); Iglehart, The New Era of Prospective Payment for Hospitals, 307 New Eng. J. Med. 1288 (1982) (discussing role of the Department of Health and Human Services in the new prospective payment plans and observing need for increased cooperation between physicians and hospitals); Morreim, The MD and the DRG, 15 Hastings Center Rep., June 1985, at 30 (DRG system presents conflict to physicians who must serve both the patients and the hospitals). Following its adoption by the federal government for the Medicare services, the DRG system has been prescribed by a number of states and private insurers in an effort to control health care costs. See Dolenc \& Dougherty, supra note 32, at 19. 
or no portion of the DRG payment under most systems represents an allocation for the free treatment of indigent patients. ${ }^{50}$ Thus, where a provider relies primarily on reimbursement through a DRG-based system, and that system's payment schedule accurately reflects actual costs of treatment, there may be no residual capacity to finance the care of uninsured patients. ${ }^{51}$

The health care system's ability to provide uncompensated care is also undercut by another recent development: the Health Maintenance Organizations (HMOs). ${ }^{52}$ Such entities essentially operate on a membership basis; individuals, for a prepaid amount, purchase the right to receive all necessary health care from a given provider. Because the upper limit of the HMO's revenue is thus fixed by the aggregate of such prepayments, the profitability of such providers, like those operating under a DRG system, depends on controlling the treatment costs of the HMO's subscribers. ${ }^{53}$ Thus, as a practical matter, the care to indigent nonsubscribers, if it is to be provided at all, must be budgeted in advance and incorporated in the membership charge. Yet an important competitive advantage HMOs typically emphasize is their relatively low cost, an advantage likely to be elimi-

50 See Howard, supra note 15 , at $323 \&$ n. 120 (noting that prospective payment plans make cost-shifting more difficult and that Medicare prohibits it entirely); Nutter, supra note 46, at 918; Thurow, supra note 40, at 612 ("In a prospective, so-much-per-patient system, . . . [t]here is going to be no slack in the system to cover those not directly covered.").

51 See Dolenc \& Dougherty, supra note 32, at 19-21 (noting impairment of cross-patient subsidization under DRG reimbursement system). Indeed, the problem is worse, for unless a DRG system is coupled with mandatory access for covered patients, providers face significant incentives to "skim" only those patients whose costs of care are likely to fall below the reimbursement schedule. The remaining patients, although insured, add to the problem of uncompensated care because their treatment will decrease, rather than supplement, the pool of funds available for treatment of the medically indigent.

Prospectively-based reimbursement systems also raise new malpractice concerns even with respect to insured patients, since providers still have an incentive to economize on treatment expenditures in order to realize a surplus from the DRG payment. For analyses of the general interrelationship between medical malpractice and cost containment, see Howard, supra note 15; Macaulay, supra note 16; Morreim, supra note 7.

52 For a general discussion of the history of HMOs, see Mayer \& Mayer, HMOs: Origins and Development, 312 New Eng. J. Med. 590 (1985).

53 Indeed, the pressure to control costs within an HMO creates its own special set of problems for a participating physician attempting to provide legally adequate care. See Bovbjerg, The Medical Malpractice Standard of Care: HMOs and Customary Practice, 1975 Duke L.J. 1375; Veatch, The HMO Physician's Duty to Cut Costs, 15 Hastings Center Rep., Aug. 1985, at 30. 
nated if they increase membership charges in order to offer extensive care to the indigent.

Moreover, the very existence of HMOs undermines cross-patient subsidization of indigent care among the non-HMO segment of the health care consumers. Such organizations essentially pool nonindigent patients and isolate their health care purchases from the rest of the patient population. This cabining of solvent groups within the consumer population exacerbates the burden of subsidy felt by the remaining nonindigent patients; the same amount of indigent care must now be financed by a smaller group of paying patients. ${ }^{54}$

Furthermore, this surviving group of potential subsidizers is probably less willing, under current market conditions, to accept without question the charges assessed by a health care provider attempting to finance care for the indigent. ${ }^{55}$ Outside the DRG and HMO context, insurers and employers have increasingly sought to control mushrooming health care costs by limiting coverage, raising deductibles, and requiring patient copayments for health care charges. ${ }^{56} \mathrm{~A}$ central goal of such changes is to encourage health care consumers to scrutinize provider charges; yet, to the extent that this effort reverses the consumer apathy generated by fuller insurance coverage, a provider's ability to incorporate the costs of uncompensated care into the charges assessed to paying patients will be limited correspondingly. ${ }^{57}$

Taken together, the above changes are likely to impair the crosspatient subsidization of indigent care: ${ }^{58}$ providers are less willing and able to administer, and consumers are less tolerant of, the collectivization of patient resources necessary to underwrite health care for the indigent. $^{59}$ Moreover, to the extent that such a system is still opera-

54 Ginzberg, supra note 32, at 757; Relman, supra note 19, at 968 .

55 Fuchs, supra note 5, at 1155 ("As the number of uninsured persons grows and the need for surcharges, local taxes, and the like increases, workers and employers who are paying for their own insurance will increasingly resent paying for the uninsured as well.").

56 See Ginzberg, supra note 45, at 1153; Schramm, Can We Solve the Hospital-Cost Problem In Our Democracy?, 311 New Eng. J. Med. 729, 729 (1984); Thurow, supra note 40.

57 See Friedman, Hospital Uncompensated Care: Crisis?, 262 J. A.M.A. 2975, 2976 (1989) (noting increased consumer resistance to cross-patient subsidization).

58 See id. at 2975 (reporting studies suggesting that hospitals are reaching limits on amount of care that can be subsidized through cross-patient cost-shifting); Bovbjerg \& Kopit, supra note 5 .

59 See Caper, Competition and Health Care-Caveat Emptor, 304 New Eng. J. Med. 1296, 1298 (1981) (hospitals reaching limits on amount of care that can be subsidized through crosspatient cost-shifting); Friedman, supra note 57, at 2976 (same); Nutter, supra note 5, at 1156 
tional, it faces an increasingly difficult task. The vast burgeoning of medical technology, ${ }^{60}$ the rapid inflation of medical costs, ${ }^{61}$ and the rise of defensive medicine ${ }^{62}$ during the last quarter century have greatly increased the costs of what is considered to be legally adequate care. Consequently, providing this level of care to the indigent has itself become a very costly proposition, one that an increasingly debilitated system of cross-patient subsidization is unlikely to manage successfully. ${ }^{63}$ Moreover, as governments have sought to control escalating health care costs through contraction of Medicare, Medicaid, and related programs, the problem has been exacerbated by the significant growth in the number of medically indigent over the last decade. ${ }^{64}$ Thus, the painful irony is that fewer funds are available to treat more indigent patients under an increasingly expensive standard of accepted practice.

A final factor undermining the willingness of health care providers to treat the poor is a perception among such providers that poor patients are more likely to file medical malpractice claims than are their more affluent counterparts. ${ }^{65}$ This perception is erroneous: for a variety of cultural and structural reasons, the poor are the least likely segment of the population to pursue malpractice claims. ${ }^{66}$ Nonetheless, the myth of the litigation-prone indigent is widely held among

(noting negative impact of changes in reimbursement systems on ability of health care providers to finance indigent care through cost-shifting); Schramm, supra note 56, at 730.

60 See generally Schwartz, The Inevitable Failure of Current Cost Containment Strategies: Why They Can Provide Only Temporary Relief, 257 J. A.M.A. 220 (1987) (discussing impact of technological change on growth of health care costs).

61 In 1960 , health care expenditures constituted $5.3 \%$ of the nation's Gross National Product. By 1987, this figure had reached $11.4 \%$. Similarly, in the same time frame, per capita expenditures on health care, measured in constant dollars, had grown from $\$ 185$ to approximately $\$ 450$. Ginzberg, supra note 45 , at 1151 .

62 See generally Note, The Medical Malpractice Threat: A Study of Defensive Medicine, 1971 Duke L.J. 939 (discussing the practice of defensive medicine by physicians but concluding that it is not as extensive as is believed).

63 For example, between 1980 and 1984, the costs of uncompensated care provided by the nation's hospitals more than doubled. Cancila, "Care of Indigents Called Critical Issue," Am. Med. News, Feb. 21, 1986, at 1, 30.

64 See Nutter, supra note 46, at 918.

65 See McNulty, Are Poor Patients Likely to Sue for Malpractice?, 262 J. A.M.A. 1391 (1989); "Medical Care for All": Questions and Answers, 260 J. A.M.A. 3106 (1988).

66 See McNulty, supra note 65 . Among other reasons, the poor are generally the least sophisticated consumers of medical services and are therefore less likely, on the whole, to perceive and seek redress for shortcomings in the quality of care provided. Moreover, lawyers are generally less willing to pursue tort claims on behalf of poor plaintiffs, since any award, 
medical practitioners, further discouraging provider efforts to extend subsidized care to the poor.

The emergence of these new constraints is likely to cause the contractual underpinnings of the physician-patient relationship to surface. As previously noted, an outright refusal to treat an indigent patient, in contrast to a decision to treat in a manner inconsistent with the unitary malpractice standard, rarely creates the threat of liability. Thus, rather than undertaking the increasingly difficult burden of financing legally adequate treatment for the indigent, the constraints make it more likely that providers will now sidestep the entire problem simply by refusing to accept some, or all, of such patients for treatment.

This prediction regarding provider behavior under the new constraints is supported by the evidence currently available. As the cost containment strategies of the 1980s have taken root, physicians and other health care providers have increasingly shunned the indigent. With respect to many individual doctors, this has occurred through a simple refusal to treat uninsured or underinsured patients. ${ }^{67}$ Hospitals, too, have increasingly withheld nonemergency care to those who lacked insurance or the means to pay for care in advance. ${ }^{68}$ And even though such patients might still enter the health care system through the mandatory access portal of the emergency room, ${ }^{69}$ the available evidence suggests that such patients are increasingly likely to be discharged or transferred to public hospitals-“dumped" in the lexicon of the profession-as soon as, and in some cases before, their conditions have been stabilized. ${ }^{70}$

upon which the lawyer's contingency fee is dependent, will typically be based on lost future earnings, which in the case of the poor is often small or nonexistent.

67 See generally Mitchell \& Cromwell, Access to Private Physicians for Public Patients: Participation in Medicaid and Medicare, in 3 Securing Access to Health Care 105 (1983) (discussing factors such as specialty, geography, credentials, competition, and political attitude that affect a physician's decision to accept voluntarily Medicaid or Medicare patients).

68 See, e.g., Hughes, Johnson, Rosenbaum \& Simons, The Health of America's Mothers and Children: Trends in Access to Care, 20 Clearinghouse Rev. 472 (1986); Wrenn, No Insurance, No Admission, 312 New Eng. J. Med. 373 (1985). More subtle strategies involve subjecting nonpaying patients to substantial waits for nonemergency services and postponing elective surgery for indefinite periods. See Friedman, supra note 57, at 2976.

69 See supra note 13.

70 See Ansell \& Schiff, supra note 13; Friedman, supra note 57, at 2976-77; Nutter, supra note 5. In most cases, such patients are transferred for economic reasons to public hospitals that are not well financed, where as a practical matter the level of care that can be provided is 
In short, as competition has undermined cross-patient subsidization of indigent care, access to health care has become increasingly dependent on ability to pay.

\section{The Continued UTILITY OF THE UnITARY STANDARD}

The foregoing analysis suggests that the effective operation of the unitary malpractice standard depends heavily on the existence of a reinforcing set of unusual market conditions. Indeed, it was the presence of these conditions, rather than the standard, that actually permitted health care providers to follow their humanitarian impulses and provide high-quality care to the indigent. With the collapse of these conditions, the unitary malpractice standard stands alone as the principal incentive encouraging health care providers to treat rich and poor alike. Yet given the ability of providers to escape tort law's reach simply by refusing to treat indigent patients, the potential of the unitary standard to achieve its goal of providing the same quality of care to all patients is, at best, quite limited.

This does not mean, however, that the unitary standard is necessarily without any enduring utility. To the extent that the traditional system of cross-patient subsidization of health care still functions, indigent patients fortunate enough to be accepted for treatment may benefit from the existence of the standard. In addition, from a process perspective, a unitary standard-with its greater ease and certainty of administration-unquestionably has advantages over more flexible formulations that account for patient resources in determining what constitutes proper care. Finally, wholly apart from these utilitarian concerns, the unitary standard's symbolic promotion of the value of equity in the provision of health care may justify its retention. ${ }^{71}$ The

lower than that at the original institution. See Schiff, Ansell, Schlosser, Idris, Morrison \& Whitman, Transfers to a Public Hospital: A Prospective Study of 467 Patients, 314 New Eng. J. Med. 552 (1986); Waitzkin, Two-Class Medicine Returns to the United States: Impact of Medi-Cal Reform, 2 Lancet 1144 (1984). Although both legislation and professional guidelines now seek to control the practice of patient dumping, the inherent vagueness of such terms as "emergency" and "patient stability" have rendered such deterrent efforts largely ineffective. See Ansell \& Schiff, supra note 13, at 1500-01.

71 See, e.g., Levey \& Hesse, supra note 46, at 645-46 ("Attempts to dismiss concerns for equality as 'merely symbolic' belittle the importance of symbolism .... The belief that society ought to pursue equal access contributes to the quality of life even though its value may be purely symbolic."). 
merits of these instrumental, process, and normative arguments for retaining a unitary standard are now considered.

\section{A. The Instrumental Value of the Unitary Standard}

The primary presumed beneficiaries of the unitary malpractice standard are the medically indigent. They are, at least in theory, guaranteed the same quality of care as paying patients. Their access to care, however, is not compelled by the standard; rather, the provision of care to the poor instead depends on government spending, direct charity, and the effective functioning of a system of crosspatient subsidization voluntarily administered by health care providers. While this collective approach may in the past have been capable of financing most indigent care, it currently falls far short of the task. The pool of funds available for indigent care has shrunk, while the demand for and the cost of such care has grown.

Under such circumstances, the value of the unitary standard to the indigent becomes questionable. While those who do obtain care are presumably protected by the standard, others are denied all access because the cost of treating them in accordance with the tort-mandated standard of care exceeds the capacity of the system to fund indigent care. This tradeoff, however, between the quality of care required and the number of patients the system can afford to treat is not immutable. Instead, for any given level of funding for indigent care, a variety of alternative balances between quality and access are possible. For example, if the standard of care for the indigent was separate from, and lower than, that of paying patients, the health care system would in theory be able to provide more of the indigent with some degree of care than is currently possible under the unitary standard.

This choice between high-quality care for a few of the poor or lower quality care for more of the poor is unquestionably second-best. By definition, the care provided the poor under the second, binary-standard option is care that a reasonable, fully-informed, paying patient would regard as inadequate. ${ }^{72}$ Yet the care provided under the uni-

72 This does not mean that the tort system under a binary standard would permit medical practitioners to provide the poor with incompetent care-that is, care that does more harm than good, or that is too costly in comparison to other treatments with equal therapeutic effect. Even under a binary standard, tort law should continue to police these problems. See infra text accompanying notes 121-42. Instead, the care received by the indigent under a binary 
tary standard, while avoiding this problem, is deficient in another respect, for it leaves more of the poor without any care at all. Neither choice, then, is optimal, but given the persistent unwillingness of American society to finance complete health care for everyone, ${ }^{73}$ these may be the only real choices the tort system has. ${ }^{74}$ The solicitous market conditions of the past never forced the issue, but with the demise of that state of affairs has come a need to rethink the unitary standard's unwavering preference for top quality over broad access. As discussed below, tort law's resolution of this tension between quality and access seems both to overlook the negative impact such a standard has on the efficient delivery of medical services to the poor and to ignore alternative approaches the law has taken in other areas where similar tradeoffs exist.

\section{Efficiency Implications of the Unitary Standard}

Naturally, determining what best serves any group, including the poor, is no easy matter. In a well-functioning market, the actual behavior of consumers typically serves as a good initial indicator of their preferences regarding safety or care in relation to other factors. ${ }^{75}$ If Volkswagens sell and Volvos do not, for example, it is probable that consumers value lower cost or better fuel economy over safety. As previously noted, however, even with respect to paying patients this contractual approach to determining consumer preferences does not work well in the medical marketplace. ${ }^{76}$ With respect to indigents, it may not work at all. They are, as a group, the least informed consum-

standard is "inadequate" only in the comparative sense of being less efficacious than that afforded to paying patients. It is, quite literally, not the best care "money could buy" if money were no object. But once the unrealistic assumption of no cost constraints is relaxed, the care provided for the poor under a binary standard may indeed become the best for the price. See infra text accompanying notes 79-80.

73 See Nutter, supra note 5, at 1157.

74 Similar tradeoffs appear in other areas where legal standards affect the distribution of scarce resources. For example, the strict enforcement of housing codes, while potentially effective in raising the quality of the housing stock available to the poor, may also both raise the price and decrease the availability of such housing. See Komesar, Return to Slumville: A Critique of the Ackerman Analysis of Housing Code Enforcement and the Poor, 82 Yale L.J. 1175 (1973); R. Posner, supra note 23, at 445-48. In such circumstances, the improved quality of housing is of no more benefit to the dispossessed than is the improved medical care mandated by the unitary standard to those unable to obtain access.

75 See generally R. Cooter \& T. Ulen, Law and Economics 22-32 (1988) (describing the theory of consumer choice and demand).

76 See supra note 26 and accompanying text. 
ers of medical services. More importantly, the very fact of their indigence deprives them of any practical ability to demonstrate their preferences through purchasing decisions. Instead, they receive the care donated to them, without having any real say in whether the quality and distribution of care thus received accurately reflects the preferences of their class as a whole. ${ }^{77}$

While actual consumer behavior thus sheds little light on the value of the unitary standard to the poor, it is still useful to speculate on what tradeoff between distribution and quality of care the indigent might choose if informed as to the amount that charity and crosspatient subsidization made available for indigent care. ${ }^{78}$ This question cannot be fruitfully addressed using the perspective of a sick patient already accepted for treatment. Such an individual, having been fortunate enough to obtain medical care, would naturally prefer the best treatment available, particularly when the costs of such care are being borne by other patients or by society at large. As such, he would rationally opt for the unitary standard because of its ability to maximize the care he receives.

Instead, this question of preference is best approached from the viewpoint of a prospective patient still outside the health care system. ${ }^{79}$ Once this ex ante perspective is adopted, the interests of the individual and the class to which he belongs begin to merge. Because an indigent individual does not know in advance whether, if he becomes ill, he will be fortunate enough to receive access to medical treatment, he can make no rational choice to favor categorically quality over access. To do so might directly contradict his own interests should he ultimately be turned away at the contractual gateway to medical care.

Instead, faced with ex ante indeterminacy regarding the success of his own future efforts to gain access to care, the best such an individual might hope for is that the fixed amount society allocates for indi-

77 See R. Posner, supra note 23, at 443 ("The willingness of a consumer, including a poor one, to pay the market price for one good in preference to another is evidence of the relative value of the goods to him .... But when the price of a good is zero, it is very difficult to estimate the value of the good to the 'buyer.' "); see also Daniels, Equity of Access to Health Care: Some Conceptual and Ethical Issues, in 2 Securing Access to Health Care 23, 34-37 (1982) (discussing problem of determining indigent preference in medical marketplace).

78 See R. Posner, supra note 23, at 436-38.

$79 \mathrm{Cf}$. id at 437 (noting advantages of ex ante perspective in assessing distributional preferences). 
gent care will be used efficiently. ${ }^{80}$ Obviously, defining efficiency in the highly complex world of modern medicine is problematic, ${ }^{81}$ but one suspects that the definition lies between the extremes of providing very limited access to perfect care and providing complete access to very limited care. ${ }^{82}$ Thus, an efficient use of the resources society allocates for indigent care might be one that cures the greatest amount of illness. ${ }^{83}$ Such a definition is useful, for by focusing on the concept of cure, it recognizes the role of quality; by considering the amount of illness cured, it acknowledges the need to spend resources wisely in order to maximize the health of indigents as a class. In this regard, the rigid constraints that the unitary standard imposes on health care

80 The distributional argument made here parallels to some extent a similar thesis advanced by the philosopher John Rawls concerning the fair distribution of scarce benefits in society. See J. Rawls, A Theory of Justice (1971). Rawls contends that distributional questions can only be properly addressed by imagining the preferences of individuals in their "original positions," that is, before their lots in life-their talents, wealth, inheritance, opportunities, and so forth-are known to them. Id. at 17-18. Under such circumstances, an individual's fear of receiving nothing would generally outweigh his hope of receiving everything. Thus, from the perspective of people in the "original position," a just society would necessarily be one that satisfied the minimum needs of all, rather than one that protects the opportunity of any individual to maximize the benefits he might receive. Id. at 151 . In the medical context, then, this approach would favor a broad distribution of adequate care over a narrow distribution of higher quality care.

Of course, Rawls's analysis is heavily dependent on his assumption that people are inherently risk-averse, an assumption that may not be true in all contexts. See R. Posner, supra note 23 , at 436-38. This potential criticism, however, seems largely inapplicable to the present context, for it is likely that most people are risk-averse, or at least risk-neutral, when it comes to their health. In other words, it is unlikely that many individuals, if placed in an "original position" regarding health care, would prefer a relatively small chance to get high quality care over a high chance to get adequate care. For further analyses of the application of Rawls's approach to the general problem of access to health care, see Buchanan, The Right to a Decent Minimum of Health Care, in 2 Securing Access to Health Care 207 (1981); Wilker, Philosophical Perspectives on Access to Health Care: An Introduction, in 2 Securing Access to Health Care 109 (1982).

81 For an extended theoretical treatment of the general problem of determining the efficient allocation of medical resources, see Gibbard, The Prospective Pareto Principle and Equity of Access to Health Care, 60 Milbank Memorial Fund Q. Health \& Society 399, 399-405 (1982).

82 See Buchanan, supra note 80; Wilker, supra note 80 .

83 The concept of "cure" is not used here in the absolute sense of a complete eradication of disease. This is what medicine strives for, but does not always achieve. Rather, "cure," as it is used here, is a more flexible concept, focusing on the avoidance of bad outcomes, such as death or complete disability, while recognizing that the total eradication of a patient's medical problem may not be cost-effective. Thus, for example, a brace and a walker might be considered a "cure" for an arthritic knee, even though the underlying condition persists and even though more expensive treatments, such as a total joint replacement, might further diminish the condition. 
providers may directly impede, rather than advance, efforts to provide maximum services to the indigent class.

The chief mischief wrought by the standard's inflexibility is that it deters health care providers from offering low cost, reasonably effective care to the poor in situations where paying patients are legally entitled to a better quality of care. ${ }^{84}$ Few medical problems respond to only one form of treatment; instead, a range of interventions, varying both in efficacy and cost, are usually available. Thus, a physician might attempt to treat a sore knee by prescribing rest, aspirin, a brace, or an artificial joint replacement. The optimal choice will vary from patient to patient, but in many cases the older, simpler, less costly treatments-treatments that alone might have constituted accepted medical practice a generation or two ago-will remain reasonably effective. To be sure, the growth of medical knowledge and technology has added more dramatic and expensive interventions to the caregiver's arsenal. Nonetheless, the incorporation of such treatments into what now constitutes accepted practice typically reflects not the complete failure of earlier approaches, but rather the ability of the newer treatments to enhance the efficacy of medical care further ${ }^{85}$

In short, yesterday's "accepted practice" may in many cases work reasonably well and be less expensive than that required of today's practitioner. The unitary standard, however, is relentlessly contemporary; past practice, no matter how efficacious, is rendered legally inadequate as soon as it is supplemented with or superseded by newer approaches. ${ }^{86}$ This mandatory bundling of old and new approaches into a single, indivisible standard potentially impairs the delivery of cost-effective care to the poor. Consider, for example, a type of infection that can be treated with penicillin both cheaply and with an $80 \%$ rate of success. If no other medication is known to be effective, treating the infection with penicillin clearly would constitute accepted

\footnotetext{
84 For a thoughtful discussion of this problem, see Bovbjerg \& Kopit, supra note 5, at 912 16.

85 Thus, for example, aspirin may serve as a good initial treatment for arthritis, with the medical option at the other end of the technological spectrum, total joint replacement, seldom being required. An orthopedist who was willing to diagnose cases of arthritis and prescribe aspirin where it might be effective, but was unwilling to perform joint replacements, would still contribute effectively to the medical well-being of many patients.

86 See generally Necheles, Standards of Medical Care: How Does an Innovative Medical Procedure Become Accepted?, 10 Law, Med. \& Health Care 15 (1982) (discussing specific medical procedures and the process of their general acceptance in the medical community).
} 
practice even though the treatment will fail in $20 \%$ of all cases. Yet if technology generates a new, more expensive antibiotic, one which adds another $10 \%$ to the rate of cure, the definition of accepted practice would probably change. The new medical protocol would require use of the new agent as a supplement to penicillin if the latter proved ineffective.

To a health care provider seeking to maximize benefits to the poor, the advent of the new technology and its incorporation into accepted practice presents a severe dilemma. Unless the provider can determine ahead of time and select only those prospective patients who will respond favorably to penicillin, it must be prepared to supply the new antibiotic for any patient who does not so respond. ${ }^{87}$ Not only is this second level of treatment more expensive on a per patient basis, it is also less effective in reducing the overall incidence of infection in the indigent population. In other words, even if the two antibiotics were priced equally, rather than health care providers spending resources on treating penicillin-resistant infections with the new antibiotic, they could treat more of the indigent successfully if new patients were accepted and treated with penicillin. ${ }^{88}$ In short, when available resources fall short of need, a penicillin-only regime will be more beneficial to the poor than the two-level response dictated by accepted practice.

This, of course, will not necessarily be the case with all ailments and all treatments. In some instances, new approaches will supplant rather than supplement older methods of treatment, either because the older methods were actually ineffective or because the new approaches are both cheaper and more effective even as an initial therapeutic strategy. Thus, the question of what constitutes cost-effective care for the poor in a world of scarce resources must necessarily be determined on a case by case basis. Yet here again tort law's unitary standard-premised on a contrary and unrealistic assumption of plen-

87 As a practical matter, some practitioners avoid this problem simply by prescribing the second generation antibiotic; the indigent patient still bears the potentially insurmountable burden of purchasing the medicine from an independent actor, for example, a pharmacy, that might safely refuse to supply the medicine without compensation. This prospect of evasion, however, simply illustrates another negative aspect of the unitary standard, its tendency to favor fragmented, compartmentalized delivery of health care over more comprehensive and integrated approaches. See infra notes 99-103 and accompanying text.

88 This is because penicillin is $80 \%$ effective with respect to its patient pool, while the second generation antibiotic is only $50 \%$ effective in combating penicillin-resistant infections. 
tiful patient resources-denies the medical profession the discretion to seek appropriate matches between disease and technology when, in fact, resources are limited. ${ }^{89}$

Indeed, if reality is allowed to supplant myth, the folly of the unitary standard becomes clear. This is not a nation where all can afford the best that medicine has to offer. Instead, the medical profession must serve at least two very different populations, one reasonably well-insured and able to afford a relatively high standard of care and the other, poor and uninsured, wholly dependent on direct and indirect forms of charity for the care that it receives. ${ }^{90}$ At one time, perhaps, cross-patient subsidization helped bridge this gap; currently it does not. A greater public commitment to insuring access to health care by all Americans might also smooth this divide, but such a commitment now resides only in the domain of political rhetoric. In a very real sense, then, the poor constitute a separate nation,,${ }^{91}$ and their health care needs should be assessed accordingly. ${ }^{92}$ To blink in the face of this painful reality and judge the medical care provided to the indigent under a standard of care derived to protect the well-off

89 One might object that the decisions of the medical profession regarding the efficacy of older treatments versus the cost of various supplements may not actually reflect the optimal preferences of the true consumer class, the medically indigent. This is, of course, possible, but given the imperfections of the medical market and the simple fact of indigence discussed above, the determination of consumer preference in this context must necessarily proceed by proxy. As such, it seems likely that the medical profession, with its ethical commitment to cure illness, its knowledge of the uses and limits of medical technology, and its control over the distribution of the surplus society allots for indigent care, stands in better stead for the poor than does the tort system. Indeed, the chief fault of the tort system, as reflected in the categorical nature of the unitary standard, is its inability to exercise discretion in determining the balance between quality and access. For general perspectives on the problems of rationing scarce medical resources, see Blumstein, Rationing Medical Resources: A Constitutional, Legal, and Policy Analysis, 59 Tex. L. Rev. 1345 (1981); Rosenblatt, Rationing "Normal" Health Care: The Hidden Legal Issues, 59 Tex. L. Rev. 1401 (1981).

90 Indeed, outside the bell jar of the unitary malpractice standard, the reality of differential health care for the poor and the nonpoor is well recognized. See, e.g., Dallek, Health Care for America's Poor: Separate and Unequal, 20 Clearinghouse Review 361 (1986); Thurow, supra note 40, at 612-13; Vladeck, supra note 6.

91 See, e.g., Blendon, Aiken, Freeman \& Corey, Access to Medical Care for Black and White Americans: A Matter of Continuing Concern, 261 J. A.M.A. 278 (1989); Kaye, Health Problems Associated with Urban Poverty: A Narrowing Gap Between the Third and First Worlds, 89 N.Y. St. J. Med. 649, 649 (1989) ("the disparity which exists between health indices in the poorest and most affluent sections of American cities ... resembles the situation found in developing countries").

92 See Kaye, supra note 91 , at 650 (suggesting that health care delivery for urban poor be structured similarly to the UNICEF model for third world countries). 
makes little more sense than would a foreign aid policy insisting that the humanitarian medical care this country supplies to impoverished nations like Ethiopia or Bangladesh match that provided by Massachusetts General Hospital. ${ }^{93}$

In addition, because the unitary standard's insistence on complete equality of treatment effectively discourages many providers from offering any treatment at all, ${ }^{94}$ the poor are forced to utilize the health care system in an inefficient manner. As previously noted, most states require hospitals to provide emergency care to the poor. ${ }^{95}$ This avenue of access to care is prone to overuse and misuse when access to treatment for nonemergency conditions is unavailable. ${ }^{96}$ This creates problems on at least two levels. First, the poor patient with early signs of illness may delay seeking help until the condition is serious enough to compel admission to the emergency room, ${ }^{97}$ at which point treatment may be both more expensive and less successful than would be nonemergency treatment provided at an earlier stage. Second, the use of the emergency room as an all-purpose treatment center for the poor fails to take advantage of the efficiencies generated by the specialization of medical practice. In other words, many of the medical conditions that are, by default, brought to the emergency room might be treated more economically and more expertly by practitioners spe-

93 Indeed, the unitary standard itself, by assuming away the question of access and focusing solely on quality, helps perpetuate the myth of a nation where all can receive the same medical care. See, e.g., Tunkl v. Regents of Univ. of Cal., 60 Cal. 2d 92, 103-04, 383 P.2d 441, 448, 32 Cal. Rptr. 33, 40 (1963) (duty of care "imports no discrimination based on economic status"). The myth is so embarrassingly contrary to fact that its persistence, in the form of a legal rule, suggests that there may be other, noninstrumental reasons for valuing a unitary standard of care. In particular, the symbolic value of the rule, its ability to describe society's hope rather than social reality, may explain its survival. This question is explored in greater detail infra Part IIC.

94 See supra notes $67-70$ and accompanying text.

95 See supra note 13.

96 See Dallek, supra note 90, at 366 (noting that the poor are often "forced to obtain episodic and expensive care from large hospital outpatient departments and emergency rooms when they can get care at all").

97 Indeed, if the ailment does not qualify as an "emergency," the hospital generally may, without incurring liability, decline to offer treatment. See Wilmington Gen. Hosp. v. Manlove, 54 Del. 15, 174 A.2d 135 (1961). 
cializing in those conditions, were such practitioners not deterred by the unitary standard's insistence on full-fare care. ${ }^{98}$

Moreover, the unitary standard may actually penalize those actors in the health care system that provide the most comprehensive, integrated care, and, in so doing, contribute to the balkanization of medical services. Although the case law is less than clear, it appears to require a caregiver only to provide those services that are within its control, and to prescribe further treatment from other practitioners when such treatment is not available from the initial caregiver.99 Thus, for example, if a physician lacked the equipment required to perform a diagnostic procedure that constituted accepted practice, she would nonetheless be able to discharge her obligation under tort law if she referred the patient to another practitioner that was able to perform such a procedure.

At this juncture, however, the contractual gateway to medical care can be resurrected. The secondary caregiver has the option of declining the referral if the patient is unable to pay for the diagnostic procedure. ${ }^{100}$ In such situations, tort law's directive is defeated; legally adequate care need only be prescribed, not provided. This result leaves open possibilities for strategic behavior. For example, a large hospital with a full range of services might be able to provide substandard care to the poor without incurring malpractice liability by segmenting itself into a series of separate corporate units, each with the separate contractual capacity to control indigent access. ${ }^{101}$ The violence of such a result stems not from the fact that it effectively denies legally adequate care to the poor: that outcome is dictated by finance, for regardless of the corporate configuration of the provider, the poor will only be treated to the extent that available funds allow. Rather, the problem with the strategic segmentation of medical services is that it may result in structures of health care delivery that, because of their compartmentalization, are less efficient at providing health care than

98 See generally Hadley, Mullner \& Feder, The Financially Distressed Hospital, 307 New Eng. J. Med. 1283 (1982) (discussing relation between, on the one hand, hospital deficits and the economic status of patients and, on the other, the misuse of emergency facilities).

99 See, e.g., Hall v. Hilbun, 466 So. 2d 856, 867 (Miss. 1985) (noting that the availability of facilities is a factor to be considered in assessing malpractice claim).

100 See supra note 14.

101 For a general discussion of the use of corporate form to evade tort law's proscriptions, see Siliciano, supra note 24. 
would be more integrated operations. ${ }^{102}$ To the extent that this phenomenon actually occurs, ${ }^{103}$ tort law contradicts its own purpose by encouraging a needless waste of resources that might otherwise be directed, at least in part, towards the care of the indigent.

In sum, if quality is defined in a collective sense-in terms, for example, of the number of lives saved or ailments relieved-rather than through a mechanistic comparison of the treatment received by different individuals, the inadequacy of the unitary standard seems clear. To be sure, the standard may ensure that a few of the indigent are treated very well, but this comes at the expense of the many. In practice, the operation of the standard resembles a lottery, where most go empty-handed so that a lucky few may be showered with riches. Even real lotteries generally are disadvantageous for their players, ${ }^{104}$ but at least they have the virtue that each participant voluntarily parts with his money in the hope of receiving a greater amount in the future. In the medical context, however, it is the unitary standard of tort law, rather than consumer choice or provider expertise, that controls how the limited pot available for indigent care is awarded. The foregoing indicates that the poor as a class may actually be harmed by the choice tort law ultimately makes on their behalf; what follows suggests that the problems created by wealth disparities have been more realistically addressed in other areas of the law.

\section{Comparative Approaches to Access by the Indigent}

The general sentiment underlying the unitary malpractice standard, that an individual's interest in health is so important that he is legally entitled to the same degree of care "[w]hether . . . a pauper or a mil-

102 See id. at $1858-59$.

103 No claim is made here as to the magnitude of such an effect, if any. The influence of tort law is simply one among many influences that may affect the configuration of the health care system, see id. at 1834, and the actual extent of its impact is a complex and largely empirical question. Rather, the point here is the simpler one that the marginal effect of the unitary standard on the overall efficiency of the health care system is likely to be negative rather than positive.

104 This is because the costs of operating the lottery, the amount the government extracts as revenue, and the lack of any interest component results in the amount paid out, on a per capita basis, being less than the amount paid in. This actuarial unfairness is, of course, typically of no concern to the avid risk preferrers that patronize lotteries. Yet, as previously noted, it is likely that the most individuals, when making access/quality tradeoffs with respect to health care, are quite risk-averse. See supra note 80 . 
lionaire,"105 is not unique. Other human interests-in food, shelter, education, and opportunity, to name a few-are of similar importance and raise similar concerns if their distribution is entirely governed by wealth. Yet this impulse towards equity is often tempered by a recognition that there are limits on the extent to which the law can, or should, attempt to redress all the inequities generated by wealth disparities. ${ }^{106}$ For example, when the state through its criminal or civil machinery acts to deprive an individual of his life, liberty, or property-interests that, at least as a constitutional matter, have been accorded even more respect than one's interest in his own health ${ }^{107}$ the quality of legal representation may be of critical importance. Yet such services, like their medical counterparts, are costly, and thus, at least as a threshold matter, an individual's ability to defend his life, liberty, or property may depend directly on his wealth.

To what extent, then, must the state, before it threatens such a deprivation, compensate for the impact of indigency on an individual's ability to defend himself? The answer to this question is instructive, for if the law is correct in insisting on complete equity of care in the medical context, where the state typically has no direct role in the transaction between physician and patient, it would seem likely that the law would be equally or perhaps even more intolerant of wealthbased distinctions where it is actively seeking to deprive an individual of a fundamental right. This, however, is not the path the law has taken.

The extremism of the medical malpractice standard can perhaps best be understood by comparing it to the criminal process, where an individual's fundamental interests in life and liberty are placed in jeopardy. The perils faced by the indigent defendant in this context have long been recognized, ${ }^{108}$ and the Warren Court voiced a proequity sentiment closely paralleling that underlying the unitary malpractice standard. For example, in Griffin v. Illinois ${ }^{109}$ the Court held that an indigent was entitled to a free trial transcript when necessary to prepare an appeal, observing that " $[t]$ here can be no equal justice

\footnotetext{
105 Becker v. Janinski, 15 N.Y.S. 675, 677 (1891).

106 For a thorough discussion of the various areas of the law affected by poverty, see $B$. Brudno, Poverty, Inequality, and the Law (1976).

107 See supra note 10.

108 See, e.g., Powell v. Alabama, 287 U.S. 45, 68-73 (1932).

109351 U.S. 12 (1956).
} 
where the kind of trial a man gets depends on the amount of money he has." 110

Nonetheless, as subsequent cases revealed, this commitment to equity proved more rhetorical than real. ${ }^{111}$ Although once dismissed as a "parochial" concern, ${ }^{112}$ the substantial cost to the state of supplying indigents with legal services identical to those that reasonably might be retained by paying clients soon became apparent, ultimately triggering a retreat from the full implications of the equity principle. Thus, for example, when the Burger Court in Ross v. Moffitt ${ }^{113}$ rejected a claim that indigents were entitled to appointed counsel when seeking discretionary review, it recast the standard as one requiring that indigents be provided an adequate, rather than an equal, opportunity to present their claims. ${ }^{114}$ The state was not required to provide " absolute equality or precisely equal advantages" "115 or to "duplicate the legal arsenal that may be privately retained" by a paying client. ${ }^{116}$ Instead, as long as indigents were provided a reasonable chance to defend their life or liberty, the concern for equity underlying cases like Griffin was satisfied.

In replacing equality with adequacy as the criterion for assessing claims regarding the proper representation of indigents in the legal system, the Court in Ross expressed strong concern over the negative impact that an opposite rule, one mandating absolute equality of representation, might have on the efficient allocation of scarce state resources. The Court observed that even states that were inclined to eradicate all wealth-based distinctions in the utilization of legal serv-

110 Id. at 19; see also Anders v. California, 386 U.S. 738, 742-43 (1967) (holding indigent petitioner entitled to counsel who will serve as his advocate); Douglas v. California, 372 U.S. 353, 356-58 (1963) (holding that, while "[a]bsolute equality is not required," indigent has right to counsel for "the one and only appeal [he] has as of right"); Draper v. Washington, 372 U.S. 487, 496-97 (1963) ("State must provide the indigent defendent with means of presenting his contentions to the appellate court which are as good as those available to a nonindigent defendant with similar contentions."); cf. Becker v. Janinski, 15 N.Y.S. 675, 677 (1891) ("Whether the patient be a pauper or a millionaire, whether he be treated gratuitously or for reward, the physician owes him precisely the same measure of duty, and the same degree of skill and care.").

111 See L. Tribe, American Constitutional Law § 16-35, at 1625 (2d ed. 1988).

112 Edwards v. California, 314 U.S. 160, 174 (1941) (invalidating statutes excluding nonresident indigents).

113417 U.S. 600 (1974).

114 Id. at 612.

115 Id. (quoting San Antonio Indep. School Dist. v. Rodriguez, 411 U.S. 1, 24 (1973)).

116 Id. at 616. 
ices "may conceivably find that other claims for public funds within or without the criminal justice system preclude the implementation of such a policy at the present time."117 This same concern over fiscal limitations has led the Court to reject similar claims, both in the criminal and civil contexts, that the state was constitutionally required to provide indigents with the same access to, and assistance in, the judicial process as was available to those with financial resources. ${ }^{118}$

The message here is an interesting one, for although the cant is conservative, the concern expressed is essentially communitarian. Unlike a unitary approach, which focuses on each individual's right to be treated the same as everyone else, the Court's approach in Ross and similar cases expressly recognizes that, in a world characterized by scarcity rather than surplus, the provision of a certain type or level of benefits to one group must be weighed carefully against any possible collateral detriment to that group or others. The solution chosen by the Court-insisting on adequate rather than equal legal representation-responds to this concern by providing a basic level of protection to the indigent without unduly limiting the legislature's discretion to marshall the state's limited resources in the most effective manner possible. ${ }^{119}$

Of course, one can criticize the Court in Ross and similar cases for treating the limited size of the state fisc as a given, wholly immune to legislative enlargement in response to the Court's constitutional rulings. A more active Court might have viewed the matter differently, concluding that if the state chose to prosecute an individual for a crime or to separate a parent from her child, it could fairly be

\section{Id. at 618.}

118 See, e.g., Scott v. Illinois, 440 U.S. 367 (1979) (no right to counsel in prosecution where imprisonment is not actually imposed); Ortwein v. Schwab, 410 U.S. 656 (1973) (per curiam) (state not required to waive $\$ 25$ filing fee for indigent seeking judicial review of state old-age assistance reduction); United States v. Kras, 409 U.S. 434 (1973) (state not required to waive $\$ 50$ bankruptcy filing fee for indigent). See generally L. Tribe, supra note 111, $\$ 16-51$, at 1647 (discussing the Court's narrowing of the indigents' right to counsel).

119 The Court's approach in Ross also implicitly recognizes another stark reality: the prospect that too unyielding an insistence on complete equality of treatment may result in strategic behavior that defeats the very purpose of the standard. Because states are under no constitutional obligation to provide any appeal in criminal cases, Ross, 417 U.S. at 611, the net effect of requiring a state to finance indigent appeals that are identical to those of paying clients might simply be to propel the state, out of fiscal concerns, to eliminate entire avenues of appellate redress. There is little to commend such an outcome, unless one subscribes to the view that misery loves company. 
required to find the resources necessary to negate completely the impact of the defendant's indigence on the process. Yet this option translates poorly to the medical malpractice context, where both the transaction affected by indigence-the treatment of the patient-and the sources of funds capable of diminishing the effects of indigence reside in the control of private parties rather than the state.

Indeed, it is precisely because tort law lacks any real ability to influence the essentially private mechanism by which much of indigent care is financed that the resource allocation concerns raised in Ross are so pertinent. If the poor's slice of the social pie is indeed fixed, cases like Ross demonstrate how the effort to promote equity through legal rules may become counterproductive. Insisting that the poor are entitled to the best money can buy in one area of need may well work a complete deprivation in another area. In such a case, rather than simultaneously experiencing both feast and famine, the poor might reasonably hope that the scarce resources society allocates for their benefit would be used judiciously to purchase adequate services in all areas of need. ${ }^{120}$ Decisions like Ross, while unquestionably not the product of an abundance of concern for the indigent, at least have the virtue of granting states the flexibility needed to achieve such a balanced outcome. The unitary malpractice standard, in contrast, loudly boasts its concern for the poor while dictating an allocation of resources that may seriously disserve their interests.

\section{B. Process Concerns and the Unitary Standard}

Although the unitary malpractice standard probably fails to fulfill its implicit goal of providing quality care to the poor, further inquiry is necessary before determining whether the rule should be jettisoned in favor of some resource-sensitive alternative. Such an inquiry focuses not on the normative concerns addressed above, but rather on how this liability rule functions within the process of litigation. Such

120 See Welch, supra note 18 , at 1264 ("Is one liver transplantation worth the price of housing for four families? The tradeoffs between health care and other social goods require careful consideration. When it is appropriate, we ought to be willing to advocate expenditures for food, housing, or education over those for medical care."). For a constitutional analysis along similar lines, see Michelman, Foreword: On Protecting the Poor Through the Fourteenth Amendment, 83 Harv. L. Rev. 7 (1969). 
"process concerns" may, in some circumstances, justify a liability rule that fails to achieve fully its normative goals. ${ }^{121}$

The process inquiry begins with a recognition that tort rules are implemented through the adjudicative process, and that the efficiency of that process, in terms of reaching consistent and predictable results at reasonable costs, is partially dependent on the structure of the liability rule to be applied. Thus, a simple rule, one that requires the trier of fact to conduct a single, discrete inquiry with respect to a readily ascertainable set of facts, generally poses few problems for the adjudicative process. As rules become more complex, however, requiring the resolution of multiple and interconnected issues, the potential for error, waste, and arbitrariness is also enhanced. ${ }^{122}$ At the extreme, the adjudicative process can completely malfunction, with outcomes dictated more by caprice than by the rational application of the law. ${ }^{123}$ In such cases, even the most substantively appropriate rules fail to achieve their intended impact.

Such concerns clearly arise in connection with a possible abandonment of the unitary malpractice standard. A central feature of that standard is its simplicity; wealth is not an issue in determining whether proper care was exercised. Any doctrinal move away from the unitary standard is therefore a move towards complexity, one that now requires the trier of fact to consider the impact of patient resources on the question of provider negligence. The inquiry is no longer limited to whether the physician supplied proper care, but instead becomes whether the physician supplied proper care in light of the patient's ability to pay for care. The added complexity of the judgment thus required by the liability standard increases the costs of

121 See, e.g., Henderson, Process Constraints in Tort, 67 Cornell L. Rev. 901 (1982) [hereinafter Henderson, Process Constraints] (examining the concept and analyzing the noduty-to-rescue rule as a consequence of process constraints); Henderson, Judicial Review of Manufacturers' Conscious Design Choices: The Limits of Adjudication, 73 Colum. L. Rev. 1531 (1973) [hereinafter Henderson, Design Choices] (arguing that process constraints prevent courts from effectively devising product safety standards); Twerski, Seizing the Middle Ground Between Rules and Standards in Design Defect Litigation, 57 N.Y.U. L. Rev. 521 (1982) (encouraging the consideration of process constraints in devising multifactored no-duty analyses).

122 See Henderson, Process Constraints, supra note 121, at 905-11; Siliciano, supra note 24, at $1826-30$.

123 See Henderson, Design Choices, supra note 121, at 1534-39. 
litigation as well as the prospects of error and arbitrariness. ${ }^{124}$ Thus, the potential exists that the normative advantages of introducing patient resource issues into the malpractice inquiry may be offset, or perhaps exceeded, by the decreased efficiency of the litigation process in producing valid results.

On the whole, however, such an untoward result appears unlikely. As an initial matter, it should be noted that despite the simplicity of the unitary standard, the malpractice inquiry already embodies a number of judgments that are no less complex than one focused on patient resources. The trier must determine what precise medical condition the patient presented, and what treatment the medical profession customarily prescribes for such a condition. Given the variability and complexity of human disease, this inquiry alone can involve a very detailed and complex judgment. In addition, other factors such as the practice specialty involved, the physical availability of diagnostic and treatment equipment, and in some cases the geographic locality of the health care provider may affect the application of the malpractice standard. ${ }^{125}$

Thus, even under the relative simplicity of the unitary standard, the factfinder in a malpractice action must perform a fairly sophisticated inquiry. To be sure, introducing the factor of patient resources into the equation further complicates matters, but the marginal increase in complexity may not be significant. Indeed, at least as a factual issue, the question of patient resources is probably far simpler to resolve than, for example, the issue of the appropriate treatment for a given condition. The patient's lack of insurance, or the degree of coverage if insurance exists, is usually readily determinable. ${ }^{126}$ Thus, the enhanced factual complexity of tort litigation under a revised standard is unlikely to pose special problems. Instead, the extent to which modification of the malpractice standard raises process concerns will depend on how factual determination of the patient's indigency at the time of treatment affects the legal determination of what constitutes adequate care.

124 Moreover, increasing the complexity of liability rules often creates new options for tort defendants to engage in strategic behavior designed to evade the force of the liability rule. See Siliciano, supra note 24 , at $1829-30$.

125 See supra note 8.

126 See Welch, supra note 18 (describing patient classification based on resource status). 
Because of the wealth-blind nature of that unitary standard, the legal significance of patient indigency has never been addressed by tort law. Analytically, however, it seems that the provision of care to the poor has three separate quality-related components, each potentially affecting the configuration of a modified malpractice rule. First, there is an allocation decision, a determination by a health care provider to expend resources to treat a specific indigent. It is important to note that, at least in theory, this decision involves not only the initial question of whether to treat a given patient, but also the ancillary question of what amount of resources should be committed to a patient accepted for treatment. Once this two-part allocation decision is made, a determination as to the method of treatment-what particular array of diagnostic and remedial techniques will be employed-is necessary. Finally, the competence with which the selected techniques are implemented provides the third component bearing on the quality of care. ${ }^{127}$

Under the existing unitary standard, the first component-the allocation decision-is simply not addressed. The law allows physicians the contractual freedom to refuse care to indigents altogether, but, if care is undertaken, the unitary standard disables providers from allocating less than full resources to treatment. This flat proscription against differentiating between accepted patients based on resource concerns also applies, under the unitary standard, to the choice of method and competence components of the treatment process: the same treatments are to be used, with the same degree of care, regardless of the patient's economic status.

Obviously, moving away from the unitary standard requires rethinking the legal significance of these three quality-related factors. The ultimate substantive goal of the law, as discussed in the previous Part, is to articulate a legal standard that allows physicians greater latitude in determining the amount and nature of the care provided the indigent, thus encouraging the voluntary treatment of greater numbers of such poor while still providing adequate assurance that the care provided will be competent and reasonable under the circumstances. Even so, consistent with process concerns, any modified

127 This Article's division of the provision of care into three components-allocation, method, and competence-is derived from a model suggested by Randall Bovbjerg. See Bovbjerg, supra note 53. 
standard must be one that, in the context of a malpractice action, can be applied in a reasonably predictable and consistent fashion by the trier of fact. These constraints suggest that some, but not all, of the quality-related issues discussed above should be factors that bear on the malpractice determination under a revised standard.

\section{Competence in the Rendering of Services}

Clearly, the simple issue of technical competence-whether the chosen diagnosis or treatment was conducted with reasonable careshould continue to be an issue under a resource-sensitive malpractice standard just as it is an issue under the unitary standard. Since the primary substantive justification for abrogating the unitary malpractice standard is to increase the overall adequacy of health care delivery to the poor, any modified standard must, at the very least, continue to protect the poor against the incompetent, that is, the harmful or wholly ineffective delivery of care. Indeed, in this context, the moral sentiment underlying that unitary standard, that all individuals deserve the same level of care regardless of their ability to pay, seems to retain full vitality. Thus, with respect to the questions of technical competence, retention of a unitary standard seems appropriate.

Similarly, in specific cases where there are no restraints on the resources allocated to treatment of an indigent patient, the unitary standard should continue to govern challenges to the provider's choices about the method of diagnosis and treatment. In other words, if the provider is willing to fund full care for a nonpaying patient, there is no substantive justification for allowing that provider to choose a less adequate (though equally costly) approach to treatment. Instead, the question of choice of method is problematic only when it is linked to the allocation decision, and specifically when it is linked to a provider's decision to devote less than full resources to the treatment of an indigent. Indeed, it is in these areas-allocation decisions and allocation-driven method decisions-that the process concerns raised by departing from the unitary standard become most significant.

As noted, the existing unitary standard largely avoids process problems in these areas by leaving the decision to treat a nonpaying 
patient to the provider, except in emergency situations, ${ }^{128}$ but by requiring full resource allocation and consistent methods of treatment if treatment is to be provided. But if tort law chooses for policy reasons to allow physicians more latitude in such areas, should the consequent allocation and methodology decisions still be subjected to some degree of judicial review? This Article suggests that, because of process constraints, the two-part allocation decision should remain entirely within the provider's discretion, but that the chosen method of diagnosis and treatment, once some resource allocation is made, is an appropriate concern of any revised tort standard.

\section{Allocations of Care and Resources}

With respect to the allocation issue, it should be noted that one component of that determination, the decision to offer any care to a patient, is already generally beyond the bounds of tort law. ${ }^{129}$ While some might argue that tort law should do more to mandate care for the poor, that is not the proposition of this Article; hence, the revised malpractice standard suggested here would do nothing to interfere with a provider's traditional contractual freedom to refuse care for the poor. Although there are independent substantive concerns for this reluctance to mandate care, ${ }^{130}$ the process problems raised by permitting judicial review of access decisions are formidable. Since society is plainly unwilling to fund full care for all of the poor, some denial of access is inevitable. If this is so, by what standards is tort law to judge an individual provider's denial of access to an individual patient? Currently, such decisions are undoubtedly the result of a multitude of factors: the physician's personal commitment to indigent care, the specific treating institution's capacity for subsidizing indigent care, the political and social consensus concerning the appropriate allocation of society's wealth towards health care for the poor, the nature of

128 See supra notes $13-14$ and accompanying text.

129 See supra note 14 and accompanying text.

130 Most notably, tort law's efforts to mandate behavior that runs strongly contrary to an actor's economic interest, which would certainly include a tort rule that required physicians to accept nonpaying patients in nonemergency situations, are more likely to be met by inefficient, strategic behavior designed to evade the rule than by willing compliance. Cf. Siliciano, supra note 24, at 1853-64 (discussing circumvention of expanded liability rules by business planners); Siliciano, Negligent Accounting and the Limits of Instrumental Tort Reform, 86 Mich. L. Rev. 1929, 1959-68 (1988) (outlining similar response of accounting profession to expanded liability rules). 
the patient's condition, the availability, cost, and scientific novelty of possible treatments, the emotional reaction provoked by the patient's plight, and so on. Given these multiple and sometimes competing concerns, the ability of tort law to formulate a workable standard for determining whether a specific denial of care was appropriate is highly doubtful. ${ }^{131}$ Indeed, as others have noted, it is in precisely such cases that the tort process, if required to resolve the issue, is likely to yield unpredictable and arbitrary results. ${ }^{132}$ Hence, on process grounds alone, the decision-to-treat component of the allocation decision should remain immune from potential tort liability,

For similar process-based reasons, the second component of the allocation decision, the amount of resources to be spent on an indigent patient accepted for treatment, should remain a medical, rather than legal, judgment. As noted earlier, many medical conditions are susceptible, with varying degrees of success and varying attendant costs, to different types of treatment. ${ }^{133}$ Locating an optimal point along this spectrum is problematic under the best of circumstances, ${ }^{134}$ but it becomes exceedingly difficult to promulgate legally governing decisional criteria when other patients, with other conditions and their own array of treatment options, are vying for the limited funds allocated to treatment of the indigent. ${ }^{135}$ Any such standard would implicitly have to resolve exceedingly complex and essentially polit-

131 Indeed, it is important to note that the main exception to the right of health care providers to refuse to treat the indigent occurs in the context of medical emergency, a context in which the patient's entitlement to access to health care can be easily and quickly determined against a single, relatively clear criterion: the need for immediate medical attention. Courts, in reviewing this determination, are able to invoke this standard as a means of reaching consistent and predictable results. Accordingly, judicial enforcement of this limited access right raises few process concerns.

132 See Henderson, Design Choices, supra note 121, at 1534-42.

133 See supra text accompanying note 85.

134 See generally Mulley \& Eagle, What is Inappropriate Care?, 260 J. A.M.A. 540 (1988) (commenting on the difficulty of reaching consensus in medical decision making). Indeed, in the medical context more care does not always correlate with better health; medical care carries its own risk of injuring the patient, and it is entirely possible that the chances of such "iatrogenic" injuries tend to rise as the degree of medical intervention increases.

135 Deciding, for example, whether aspirin, a brace, or a joint replacement is appropriate treatment for a specific patient with an arthritic knee is often a complex medical judgment, but, when the choice made directly affects the amount of resources available to treat other patients, the analysis becomes geometrically more complex. The relevant inquiry is no longer what is best for the individual patient, but rather is what maximizes the "health," however that term is defined, of the indigent patient class as a whole. See supra text accompanying notes 80 83. 
ical questions that society has, thus far, shown little success in negotiating. These questions include whether we as a society prefer to treat large numbers of the poor with minimum levels of care, or limited numbers of the poor with full care, or something in between; whether we wish to focus resources on certain diseases and conditions over others; and whether we want to allow such criteria as age, family status, or potential social contribution to affect the decision to offer treatment.

To be sure, leaving this multifaceted resource allocation decision to health care professionals might yield inconsistent outcomes, with poor patients suffering similar conditions receiving different amounts of care. ${ }^{136}$ Yet there is little hope that the tort system, functioning through numerous, independent lay juries acting in unrelated lawsuits, would produce any better results. Indeed, the tort system is almost certain to do worse, for juries in individual actions, when confronted with an injured and sympathetic plaintiff, are easily distracted from the broad social implications of individual allocation decisions. The jury's answer in such cases will almost always be that more should have been done; that, however, is an answer that society has steadfastly refused to finance. Moreover, absent some overriding political directive, the medical profession is clearly better trained than the legal profession to practice the cold art of triage that is necessary when resources are inadequate, and thus should be allowed to make resource allocations free from the second-guessing of tort law.

\section{Selection of Methods of Diagnosis and Treatment}

Finally, a revised standard must take some stance regarding the choice of method in circumstances where an allocation for some, but not full, care has been made. Conceivably, tort law could leave this type of decision, like the allocation choices just discussed, to the discretion of the health care provider. However, subjecting the method decision to the scrutiny of tort law serves important substantive interests, while raising fewer process concerns than would occur were allocation decisions subject to potential tort liability.

136 As noted below, it is likely that over time such inconsistency will be corrected by the development of protocols for the treatment of each subclass of consumers of medical care. See infra text accompanying note 140 . 
On the substantive level, encouraging providers to use the funds they have allocated to treatment of an indigent patient prudently-in other words, to exercise reasonable care in making diagnostic and treatment choices-clearly falls within tort law's overall goal of insuring that the poor receive quality health care. Indeed, it would make little sense to insist, as current law already does, that diagnostic and treatment techniques be performed carefully, without also insisting that the techniques thus performed be appropriate to the patient's condition. An error in either arena, careless choice of the treatment approach or careless performance of that approach, has the same undesirable result: scarce medical resources are wasted without improving the condition of the indigent patient. Thus, method decisions, like competence, are appropriately subject to tort review.

On a process level, tort liability for inappropriate choices of diagnostic and treatment methods does not raise the kinds of concerns noted above in relation to allocation choices. The patient has already been accepted for treatment; hence, tort law is not faced with complex questions relating to the relative merits of the competing claims by others for the same medical resources. Instead, the only question is whether the resources spent were well spent, a question not significantly different in kind or difficulty from the traditional malpractice question of whether the services performed were performed carefully. Indeed, as noted, method choices were already subject to tort scrutiny under the unitary standard. ${ }^{137}$ The only difference under the revised standard proposed here is that such method choices are no longer assessed against a unitary assumption of full resources, but instead must be judged against whatever level of resources were actually allocated to treatment of a particular patient.

This task, of course, poses some process problems, for once the traditional assumption of full care is jettisoned, the "customary" practice of the medical profession with respect to a given condition no longer serves as an automatic benchmark for reasonable care. Instead, for any given condition, the appropriate response will now depend not only on what is medically indicated, but also on what is financially feasible. The interjection of this resource question into the equation undoubtedly increases the complexity of the malpractice

137 See Bovbjerg, supra note 53, at $1385-86$ \& n.31. 
determination, but there are reasons to believe that the tort process can handle the added burden.

First, in many other areas where tort law concerns itself with the safety of a good or the carefulness of a service, it already adjusts its inquiry to account for the amount that the plaintiff paid for the good or service. As previously noted, tort law does not insist that Volkswagens be as safe as Volvos, ${ }^{138}$ nor does it require that a Legal Aid attorney handle a client's matrimonial problems in the same manner as would Donald Trump's team of lawyers. ${ }^{139}$ Indeed, the unitary medical malpractice standard is distinctive in large part because of departure from tort law's general recognition of the inevitable interplay between quality and cost. Thus, although a resource-sensitive malpractice standard is doubtless more difficult to administer than a unitary one, it presents no special challenge that tort law has not already met and mastered in other, similar areas of concern.

Moreover, it is unlikely that the single, customary treatment now prescribed under the unitary standard will give way to an infinitely variable number of treatments, the reasonableness of each depending on the precise dollar amount allocated to the care of each specific indigent. Instead, methods of diagnosis and treatment tend to be limited in number, and allocations of resources to patient care tend to come in discrete increments. ${ }^{140}$ As such, the traditional test of customary care is likely to retain its vitality, although it will appear in a stratified rather than a unitary form. In other words, as with other goods and services, medical care will be delivered in distinct tiers, ranging from budget to boutique, with method-decision choices triggering malpractice liability only when the care delivered was inadequate in light of the resource allocation. ${ }^{141}$

138 See supra note 3 and accompanying text. Indeed, in the legal malpractice context, the concept that the amount of service owed a client is dependent upon the amount of service that the client has agreed to pay for is virtually unquestioned. The attorney-client relationship is viewed as essentially contractual in nature, with the terms of the engagement generally establishing both the services to be provided and the compensation to be received. See $R$. Mallen \& J. Smith, Legal Malpractice $\S 2.9$ (3d ed. 1989). Malpractice concerns generally arise only when the attorney fails to fulfill the terms of the engagement or does so in an incompetent manner. But the attorney is typically under no obligation to provide services beyond the scope of the agreed-to representation. Id. $\S 24.22$.

139 See supra notes 107-18 and accompanying text.

140 See, e.g., supra note 85 and accompanying text.

141 See Welch, supra note 18. Indeed, the ultimate and ironic result of liberating the malpractice standard from the current assumption of unlimited resources may be the 
In sum, the normative concerns discussed in the first Part of this Article can be satisfied under a resource-sensitive standard consistent with process concerns. To do so, the unitary standard must be modified, but only to a limited extent. The decision to offer care to a particular indigent patient would remain beyond the reach of tort law, as would the provider's newly sanctioned ability to allocate less than full resources to the care of such a patient. But, following these allocation decisions, both the reasonableness of the provider's decisions as to methods of diagnosis and treatment and the competence with which the care was actually rendered would be governed by the malpractice standard. ${ }^{142}$

\section{The Symbolic Value of the Unitary Standard}

Although the instrumental value of the unitary standard in encouraging the provision of quality care to the poor is dubious, and the process costs of moving to an alternate, resource-sensitive standard are likely to be manageable, amending the unitary standard in the manner suggested may have important symbolic connotations. Despite its practical drawbacks, the unitary standard expresses a widely-held ideal. As an abstract proposition, most would want the

emergence of a new sort of unitary standard. Unlike the existing standard, however, such a revised rule would focus on the minimally accepted level of care that any patient, rich or poor, should be accorded. Basic care, decent care, and adequate care would become tort law's concern. Freed of a task it could not accomplish, tort law could pursue a more humble but also more realistic vision of equity. Contract would pick up the slack, allowing those patients who could afford the fancier care offered by medical technology's relentless march to contract specifically for such heightened levels of care. And with this deflation of tort law's ambitions, many of the process advantages of a unitary standard would be retained.

142 It is unlikely that the modification of the unitary standard suggested here could come about through judicially generated tort reform. Health care providers have little incentive to challenge the standard by providing substandard care to the poor in the hope that a subsequent malpractice litigation will result in amendment of the tort standard when they have the riskfree option of simply refusing to treat the poor at all. Indeed, this dynamic probably explains why such a seemingly dysfunctional component of tort law has gone largely unquestioned. Reform, if it is to come at all, probably must be at the hands of the legislature. To be sure, this route is not particularly promising, for although the standard has little affirmative symbolic value, the negative political impact of appearing to be "against the poor" may dissuade politicians from supporting necessary reform efforts. The recent efforts of states such as Oregon to address the problems of medical scarcity, however, do hold out hope that legislatures might possibly succeed in elevating substance over form. 
poor to enjoy quality health care, ${ }^{143}$ and the unitary standard serves as a dramatic, public means by which we articulate that noble sentiment. Therefore, even if the standard is wholly ineffectual in achieving its implicit goal, rejecting it in favor of the resource-sensitive alternative proposed here risks destroying the symbolic commitment to equity embodied in the standard. As one set of commentators has noted, this consequence alone deserves attention, for the "belief that society ought to pursue equal access contributes to the quality of life even though its value may be purely symbolic."144

The question, then, is whether the symbolic significance attached to the standard justifies its retention, despite its instrumental deficiencies discussed above. This question is difficult to assess in the abstract. The law could easily adorn itself with all sorts of vague, symbolic directives which, on some level of abstraction, would be morally pleasing to everyone, but that aesthetic response alone does not tell us whether such a move would be worth its cost. Instead, accurately assessing the symbolic importance of the unitary standard requires a more detailed inquiry into who actually benefits from the standard's promotion of the ideal of equity, and why.

The medically indigent are the group most directly affected by the standard, and it may be that the symbolic benefits they receive from the unitary standard outweigh the practical costs it imposes on their access to health care. After all, the standard does affirm that, at least in the eyes of tort law, they are as deserving of good health as any member of society. Although this validation should not be trivialized, there is still reason to doubt its actual significance to the medically indigent. First, unlike other legal embodiments of the ideal of equitable treatment, such as the equal protection guaranties of the Constitution, the unitary standard is hardly a bright star in the legal firmament. The poor, as a class, generally underutilize the malpractice remedy, ${ }^{145}$ and thus probably have little real knowledge or appreciation of the noble stance tort law takes regarding the appropriate quality of indigent care.

143 Blendon, What Should Be Done About the Uninsured Poor?, 260 J. A.M.A. 3176 (1988) (noting that most Americans view quality health care as a civic right but, at the same time, are unwilling to pay the amount of additional taxes necessary to finance fully such care).

144 Levey \& Hesse, supra note 46 , at $645-46$.

145 See McNulty, supra note 65. 
More importantly, however, the poor are quite unlikely to regard that stance as noble. Even if they were aware of the standard, they would doubtless have difficulty viewing it apart from the free market system to which it is securely tethered. In other words, the symbolic affirmation of equality embedded in the unitary standard loses much of its force when it is preceded by tort law's other message in this context: that absent an emergency, indigent patients have absolutely no right of access to the health care system. ${ }^{146}$ Symbols, no matter how high-minded and well-meaning, cannot heal, and hence the unitary standard's promise of cake when many of the poor lack even the bread of minimally adequate care is much more likely to generate cynicism than appreciation.

Nor is the unitary standard likely to have much symbolic importance to health care providers. As noted earlier, by virtue of their training and professional ethic, physicians are generally inclined to provide the best care possible to their patients. ${ }^{147}$ They are unlikely to need tort law's approval in this regard. Indeed, if anything, the unitary standard interferes directly with their professional mission by discouraging them from offering adequate care to the poor in situations where the resources required for full care are unavailable. The health profession is deeply concerned with the problems of caring for the indigent, ${ }^{148}$ and most proposals for reform recognize the need to stratify the delivery of care in order to improve service to the poor. Thus, rather than perceiving the unitary standard as an aspirational command, health care providers are likely to find it an irksome and clumsy impediment to the important task of efficiently rationing the scarce medical resources society allocates to treatment of the indigent.

If neither the poor nor their medical caretakers derive symbolic value from the unitary standard, who does? Perhaps the answer is that society, or at least tort law, benefits from the unitary standard's symbolic commitment to equitable treatment. Such a conclusion, of course, requires personifying society and tort law, giving them a moral conscience and a conscious appreciation of the configuration of

146 See supra notes $13-15$ and accompanying text.

147 See supra text accompanying notes 41-42.

148 See, e.g., Lundberg \& Bodine, Fifty Hours for the Poor, 262 J. A.M.A. 3045 (1989) ("One of the characteristics of a true profession remains its special relationship with the poor. ... The privilege to practice ... medicine has carried with it the obligation to serve the poor without pay."). 
specific liability rules. Realistically speaking, this is nonsense. At best, a relatively small number of judges, tort scholars, and members of the public are even aware of the posture tort law takes towards medical care for the indigent, and even using them as a proxy for determining how tort law and society as a whole might value the unitary standard fails to answer whether that the standard deserves retention.

The answer depends in part on whether the standard represents an aspiration towards which society is willing to work, or a gesture that is unmatched by any substantial commitment of effort. In the former case, a rule with important symbolic significance might be tolerated despite its instrumental shortcomings, for it at least serves as a beacon towards which society's movement can be directed. But in the present case, the unitary standard appears to represent mere tokenism. Given the free market context in which it is embedded, the rule itself is largely ineffectual in promoting the health care needs of the poor. And, despite a good deal of political posturing and public angst about the problems of the medically indigent, society appears nowhere near ready to commit the resources necessary to make the standard's prescription meaningful, that is, to provide the same quality of health care to all regardless of economic status.

Indeed, the role of this overarching attitude towards the poor in depriving the unitary standard of positive symbolic value can perhaps best be understood by examining the overall symbolic connotations of a closely parallel feature of tort law: the Good Samaritan Rule. Under this rule, a person who voluntarily attempts to aid another person in peril, just as a physician who voluntarily undertakes to treat an indigent patient, owes that person the same duty of reasonable care that he would if the assistance was rendered for consideration. ${ }^{149}$ Thus, tort law pronounces that the care provided the helpless, like that given the poor, should not be of any lower quality because of the recipient's unfortunate status. Yet this positive, equality-championing sentiment is hardly what first-year law students notice, and balk at, when they initially encounter the Good Samaritan Rule. Instead, this requirement of reasonable care, like the unitary malpractice standard, is but a quiet exception to the general, contrary rule which

149 See, e.g., Black v. New York, N.H. \& H.R. Co., 193 Mass. 448, 450, 79 N.E. 797, 798 (1907); Zelenko v. Gimbel Bros., 158 Misc. 904, 287 N.Y.S. 134 (Sup. Ct. 1935). 
in the rescue context provides that, absent some special, preexisting relationship, there is no duty to rescue someone in peril even if the aid could be rendered without cost, danger, or inconvenience to the rescuer. ${ }^{150}$

Thus, the central symbol in the Good Samaritan context is not carefulness, but the utter freedom to disregard the needs of others. There may be strong policy justifications for this rule; ${ }^{151}$ that is not the issue here. Instead, the simple point is that the rule's central emphasis on individual freedom, like the importance of contractual freedom in the medical care context, fairly overwhelms any symbolic gesture toward equality and communitarianism that might be reflected in a minor exception to that rule. Put bluntly, if able-bodied bystanders are free to watch helpless infants be crushed by slow-moving trains, tort law's admonition to would-be rescuers to act carefully is, as a symbol, laughably insignificant. Similarly, given the right of health care providers to close their doors to the medically indigent, the symbolic importance of a rule governing how those fortunate few who do gain admittance are to be treated should not be overestimated.

\section{CONCLUSION}

The ultimate failure of the unitary medical malpractice standard to achieve its goal of securing quality health care for the poor tells us a good deal about the dangers of using instrumental reasoning when it is detached from political and economic reality. The sentiment underlying the standard is obviously laudable, but the behavioral model invoked by tort law is embarassingly naive. Tort law instructs health care providers to treat the poor the same as the rich, but then blithely ignores the fundamental impact that resource scarcity and the provider's freedom to refuse care to the poor have on the efficacy of its command. By denying these actualities, tort law is able to hide from the fact that its rule, rather than assisting the poor, actually impairs the efficient delivery of medical benefits to that group.

\footnotetext{
150 See, e.g., Buch v. Amory Mfg. Co., 69 N.H. 257, 261, 44 A. 809, 811 (1898).

151 See generally Henderson, Process Constraints, supra note 121, at 928-43 (stating that the no-duty-to-rescue rule is a consequence of process constraints); Landes \& Posner, Salvors, Finders, Good Samaritans, and Other Rescuers: An Economic Study of Law and Altruism, 7 J. Legal Stud. 83 (1978) (noting that the common law no-duty regime is economically efficient). But cf. Weinrib, The Case for a Duty to Rescue, 90 Yale L.J. 247 (1980) (arguing in favor of a judicially created duty to rescue).
} 
Facing this reality is sobering and painful. The poor are healed not by good thoughts, but by good deeds. In an ideal world, society would surely commit greater resources to the care of the indigent. But society has not done so, and tort law is relatively powerless to precipitate such a decision. Instead, the most tort law can do-and it is not a great deal-is to structure its liability rules in a way that encourages providers to maximize the beneficial impact of the limited resources available for care of the indigent. As suggested above, the unitary standard fails even at this narrow task. By embracing the chimera of equality between the rich and poor, it effectively disables health care providers from offering reasonable, low-cost care to large numbers of the medically indigent. Thus, through its adherence to the unitary ideal, tort law may end up killing the poor with an unthinking and misguided kindness. 